2015

\title{
Quantifying Florida Bay Habitat Suitability for Fishes and Invertebrates Under Climate Change Scenarios
}

\author{
Kelly A. Kearney \\ Mark J. Butler IV \\ Old Dominion University, mbutler@odu.edu
}

Robert Glazer

Christopner R. Kelble

Joseph E. Serafy

See next page for additional authors

Follow this and additional works at: https://digitalcommons.odu.edu/biology_fac_pubs

Part of the Climate Commons, Ecology and Evolutionary Biology Commons, and the Marine Biology Commons

\section{Repository Citation}

Kearney, Kelly A.; Butler, Mark J. IV; Glazer, Robert; Kelble, Christopner R.; Serafy, Joseph E.; and Stabenau, Erik, "Quantifying Florida Bay Habitat Suitability for Fishes and Invertebrates Under Climate Change Scenarios" (2015). Biological Sciences Faculty Publications. 120.

https://digitalcommons.odu.edu/biology_fac_pubs/120

\section{Original Publication Citation}

Kearney, K. A., Butler, M., Glazer, R., Kelble, C. R., Serafy, J. E., \& Stabenau, E. (2015). Quantifying Florida Bay habitat suitability for fishes and invertebrates under climate change scenarios. Environmental Management, 55(4), 836-856. doi: 10.1007/ s00267-014-0336-5 
Authors

Kelly A. Kearney, Mark J. Butler IV, Robert Glazer, Christopner R. Kelble, Joseph E. Serafy, and Erik Stabenau 


\title{
Quantifying Florida Bay Habitat Suitability for Fishes and Invertebrates Under Climate Change Scenarios
}

\author{
Kelly A. Kearney $\cdot$ Mark Butler $\cdot$ Robert Glazer • \\ Christopher R. Kelble · Joseph E. Serafy • \\ Erik Stabenau
}

Received: 15 August 2013/ Accepted: 10 July 2014/Published online: 13 September 2014

(C) Springer Science+Business Media New York 2014

\begin{abstract}
The Florida Bay ecosystem supports a number of economically important ecosystem services, including several recreational fisheries, which may be affected by changing salinity and temperature due to climate change. In this paper, we use a combination of physical models and habitat suitability index models to quantify the effects of potential climate change scenarios on a variety of juvenile fish and lobster species in Florida Bay. The climate scenarios include alterations in sea level, evaporation and precipitation rates, coastal runoff, and water temperature. We find that the changes in habitat suitability vary in both magnitude and direction across the scenarios and species, but are on average small. Only one of the seven species we investigate (Lagodon rhomboides, i.e., pinfish) sees a sizable decrease in optimal habitat under any of the scenarios. This suggests that the estuarine fauna of Florida Bay may not be as vulnerable to climate change as other components of the ecosystem, such as those in the marine/terrestrial ecotone. However, these models are relatively simplistic,
\end{abstract}

Electronic supplementary material The online version of this article (doi:10.1007/s00267-014-0336-5) contains supplementary material, which is available to authorized users.

K. A. Kearney $(\square)$

Division of Marine Biology and Fisheries, University of Miami Rosenstiel School of Marine and Atmospheric Science,

4301 Rickenbacker Causeway, Miami, FL 33149, USA

e-mail: kkearney@rsmas.miami.edu

M. Butler

Department of Biological Sciences, Old Dominion University, Norfolk, VA 23529-0266, USA

R. Glazer

Florida Fish and Wildlife Conservation Commission, Fish and Wildlife Research Institute, 2796 Overseas Highway, Ste. 119, Marathon, FL 33050, USA looking only at single species effects of physical drivers without considering the many interspecific interactions that may play a key role in the adjustment of the ecosystem as a whole. More complex models that capture the mechanistic links between physics and biology, as well as the complex dynamics of the estuarine food web, may be necessary to further understand the potential effects of climate change on the Florida Bay ecosystem.

Keywords Climate change $\cdot$ Scenario modeling $\cdot$ Sea level rise $\cdot$ Fisheries

\section{Introduction}

Coastal estuaries and bays are of great ecological and economic significance (Pendleton 2010), and they produce a diversity of ecosystem services that benefit humans (Barbier et al. 2011). Their close proximity to human populations and high productivity make them some of the most heavily utilized and threatened ecosystems on the planet (Halpern et al. 2008; Lotze et al. 2006). Urban, suburban, and agricultural development of coastal watersheds have led to

\section{R. Kelble}

NOAA Atlantic Oceanographic and Meteorological Laboratory, 4301 Rickenbacker Causeway, Miami, FL 33143, USA

J. E. Serafy

NOAA National Marine Fisheries Service, Southeast Fisheries

Science Center, 75 Virginia Beach Drive, Miami,

FL 33149, USA

\section{E. Stabenau}

National Park Service, Everglades National Park, 950 N. Krome Ave., Homestead, FL 33130, USA 
destruction of wetland habitats, as well as profound hydrological alterations that modify surface and groundwater dynamics and can in turn change salinity regimes "downstream" in receiving water-bodies (Estuar Coast Shelf S Special Section 2012).

Florida Bay (Fig. 1), which is located at the southern end of the Florida Peninsula and lies at the terminus of one of the world's largest wetlands - the Everglades, is an example of an estuary whose hydrodynamics have been substantially altered by humans (Light and Dineen 1994; McIvor et al. 1994), especially with respect to salinity. The building of spoil islands along Florida Bay's southern border for the construction of the Florida Overseas Railway in the early 1900s restricted circulation in Florida Bay (Swart et al. 1996). Likely more significant was the drainage and water management within the upstream Everglades ecosystem over the twentieth century, which decreased freshwater flow to Florida Bay by as much as $59 \%$ (Smith et al. 1989) and increased salinity in parts of the bay closest to freshwater input locations by 14 psu (Marshall and Wingard 2012; Marshall et al. 2008). These changes to Florida Bay have resulted in more frequent and intense hypersalinity events (Fourqurean and Robblee 1999) as a result of the decreased freshwater runoff and long residence times in north-central Florida Bay (Lee et al. 2006). The current salinity regime has significant seasonal variability, with hypersalinity during the summer months and estuarine salinities in the fall and winter (Kelble et al. 2007). Hypersalinity events are especially pronounced ( $>50 \mathrm{psu}$ ), when the onset of the wet season is delayed, and these high salinities can lead to significant ecological impacts (Fourqurean and Robblee 1999).

In 1987, Florida Bay experienced a significant seagrass die-off, followed in the next few years by increased phytoplankton blooms and increased turbidity (Fourqurean and Robblee 1999). These changes significantly impacted the fauna of Florida Bay, resulting in decreased lobster populations and sponge die-offs (Butler et al. 1995). Conditions in the Bay have since improved (Boyer et al. 2009; Madden et al. 2009), but episodic bloom and die-off events have continued to occur through this decade, and there remain significant concerns that this ecosystem is at risk without more effective management actions.

Florida Bay provides a number of ecosystem services (Kelble et al. 2013b; Cook et al. 2014) and is frequently utilized by the human population, largely for recreational fishing (Tilmant 1989; Osborne et al. 2006). Although the recreational fishery targets a diversity of species, gray snapper (Lutjanus griseus), and spotted seatrout (Cynoscion nebulous) account for over $60 \%$ of the recreational finfish catch (Tilmant 1989). The fishery for the Caribbean spiny lobster (Panulirus argus) is the single most economically valuable fishery in Florida and the Caribbean
(Ehrhardt et al. 2010), and in Florida the recreational lobster fishery accounts for $20 \%$ of all lobster landings. Recreational fishing of lobster is not permitted within the Everglades National Park boundaries of Florida Bay, but the southern portion of the bay is an important lobster nursery (Herrnkind et al. 1997).

A recent analysis of stressors impacting the Florida Bay ecosystem showed that changes in the physical environment were more impactful to the ecosystem as a whole than the recreational fishery. Specifically, it identified the dominant pressures to be fresh water delivery, sea level rise, and climate-related alterations in temperature and weather (Cook et al. 2014). Thus, tools are needed that allow us to better examine and predict the impact of climate change on the fauna of Florida Bay. The present study presents the integration and application of hydrodynamic and ecological models to examine the impact of the potential climate change scenarios as proposed in this issue (Obeysekera et al. 2014; Havens and Steinman 2013) on key species within Florida Bay. Understanding these impacts may allow for the implementation of management actions that address the likely impacts of climate change.

To quantify the potential change in habitat quality for key faunal species caused by climate change, we make use of a variety of habitat suitability index models. Habitat suitability index (HSI) models represent a quantitative synthesis of species-specific information on habitat utilization and/or preference. They are simple mathematical expressions, derived empirically from field and/or laboratory observations, that convey habitat quality for a particular species or population as a function of one or more environmental variables. Typically, HSI models are used to assess the quality of a given geographical area for a specific population when modified by some combination of anthropogenically driven environmental changes, and they are increasingly being used to examine potential climate change impacts on a diversity of organisms, including fishes (Chang et al. 2013; Cline et al. 2013; Jones et al. 2013). In coastal ecosystems, these modifications may include alterations of terrestrial landscapes, hydrology and/ or sediment dynamics, as well as changes to nutrient, temperature, dissolved oxygen, and salinity regimes. By mapping HSI values, changes in suitable habitat area and configuration under different management or climate scenarios can be visualized and communicated to managers. Therefore, HSI models have utility in natural resource decision-making by improving understanding of specieshabitat relationships and by serving as specific hypotheses that can be tested and improved via empirical studies.

In this study, we use a combination of new and existing HSI models relating temperature and salinity characteristics to habitat suitability for a variety of species that reside in Florida Bay, including juvenile fishes and lobsters. We 


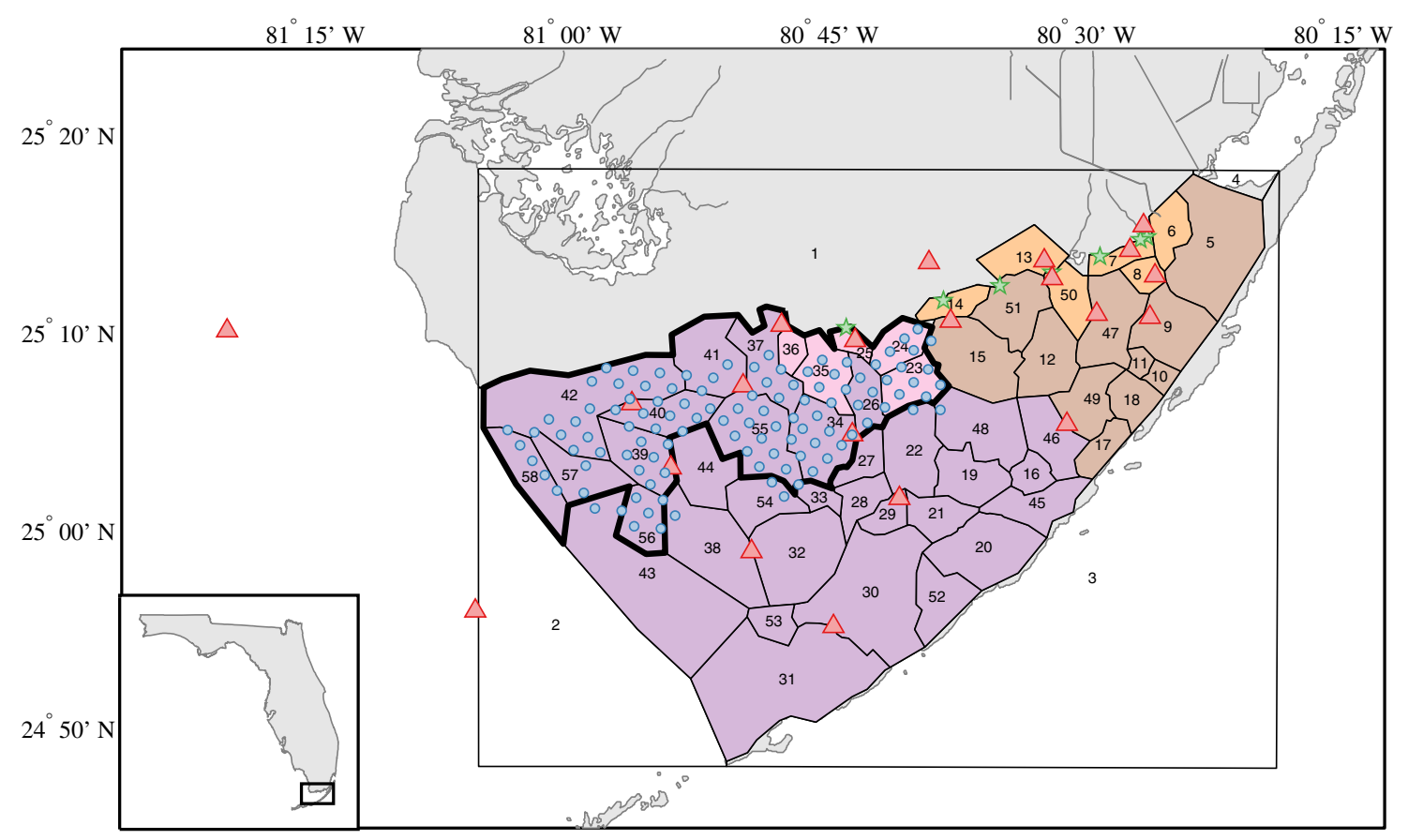

Fig. 1 The FATHOM model simulates exchange between 58 basins, which are indicated on the map as black lines. The basins outlined by the thick black line indicate the sampling region over which most of our HSI calculations were applied. Also shown are the locations of the juvenile fish data collection macrocells (circles, blue) and Marine Monitoring Network stations (triangles, red). Stars (green) along the

then apply these habitat suitability models to the output of a time-dynamic mass-balance model that simulates the changing salinity conditions of the Bay under a series of climate change scenarios.

\section{Methods}

Modeling the Physical Effects of Climate Change Scenarios on Florida Bay

We used the Flux Accounting and Tidal Hydrology at the Ocean Margin (FATHOM) model, a coastal model, to predict salinity conditions for Florida Bay. FATHOM is a spatially explicit box model that uses tidal forcing to move water across the multitude of shallow banks that separate Florida Bay into 58 discrete basins; the model has been demonstrated to reproduce observed salinity patterns throughout Florida Bay. (see Cosby et al. 2004, for details). The model operates at $1 \mathrm{~min}$. time steps, calculating the transfer of water across the banks due to surface level differences between basins using the Manning equation for flow in shallow channels. At each time step, fresh water is either added or removed from each basin due to precipitation and evaporation, and then salinity is recalculated. coastline indicate the locations of freshwater input to the Bay from coastal creeks; from west to east these are McCormick Creek, Taylor River, Mud Creek, Trout Creek, Stillwater Creek, West Highway Creek, and Highway Creek. The basins are colored according to the regions used to present our results: west purple, west inshore pink, east brown, and east inshore orange

Because the model assumes well-mixed basins, model results are presented in monthly time steps.

The scenarios investigated using FATHOM are all modifications of a base scenario representing the observed conditions between 1965 and 2000. Input variables, including precipitation, evaporation, freshwater discharge, and sea level timeseries, were increased or decreased to reflect the conditions expected during future hydrologic regimes as projected by Obeysekera (2014), while maintaining the seasonal patterns in the original data set. Details of these modifications are provided in the scenario descriptors below. This approach allows the model to simulate future scenarios while including historical temporal variability. Throughout this paper, we refer to the various simulated climate scenarios using abbreviations for each environmental variable that was manipulated:

1. Sea level (SL): The baseline state (SL0) uses observed coastal water levels, marsh water levels, and salinity boundary conditions as input to the FATHOM model. The increased sea level state (SL+) applies an additional $18^{\prime \prime}(45.7 \mathrm{~cm})$ to the water levels in all basins.

2. Evaporation rate (EVP): The baseline state (EVP0) evaporation rates were derived from air temperature variability measurements, as described in Cosby et al. 
Table 1 Juvenile fish count trawl data

\begin{tabular}{|c|c|c|c|c|}
\hline Common name & $\begin{array}{l}\text { Scientific } \\
\text { name }\end{array}$ & Number & Fraction & $\begin{array}{l}\text { Average } \\
\text { number }\end{array}$ \\
\hline $\begin{array}{l}\text { Spotted Seatrout } \\
\quad<100 \mathrm{~mm}\end{array}$ & $\begin{array}{l}\text { Cynoscion } \\
\text { nebulosus }\end{array}$ & 3,615 & 0.0999 & 2.1 \\
\hline Gray Snapper & $\begin{array}{r}\text { Lutjanus } \\
\text { griseus }\end{array}$ & 3,615 & 0.1524 & 2.6 \\
\hline $\begin{array}{l}\text { Goldspotted } \\
\text { Killifish }\end{array}$ & $\begin{array}{l}\text { Floridichthys } \\
\text { carpio }\end{array}$ & 297 & 0.1279 & 9.3 \\
\hline Rainwater Killifish & Lucania parva & 297 & 0.5758 & 64.4 \\
\hline Mojarra & $\begin{array}{l}\text { Eucinostomus } \\
\text { spp. }\end{array}$ & 297 & 0.8956 & 55.1 \\
\hline Pinfish & $\begin{array}{l}\text { Lagodon } \\
\quad \text { rhomboides }\end{array}$ & 297 & 0.4983 & 37.6 \\
\hline
\end{tabular}

Data include common and scientific name of each species, number of trawl datasets where a species was quantified, fraction of those datasets where the species was observed, and the average number of each species observed in the fraction of datasets where they were present

(2004) and references therein. The increased evaporation state (EVP+) forcing is based on the bulk aerodynamic flux equation (Pond et al. 1974) that has previously been employed in Florida Bay (Kelble et al. 2007; Smith 2000). The equation was adjusted to account for differences in evaporation due to a $1{ }^{\circ} \mathrm{C}$ temperature increase, and the resultant monthly timeseries was provided as input to the FATHOM model.

3. Rainfall and runoff (RF): The baseline state (RF0) uses observed precipitation rates and observed discharge from coastal creeks. The increased state (RF+) adds a $10 \%$ increase in precipitation rates and corresponding $5 \%$ increase in freshwater flow from the coastal creeks. The decreased state (RF-) decreases precipitation rates by $10 \%$ and decreases freshwater flows by $5 \%$. The 2:1 correction for freshwater flow from the coastal creeks located along northeastern Florida Bay (Fig. 1) was based on the relationship between precipitation data in the upstream marsh and measured creek discharge data (South Florida Natural Resources Center Everglades National Park 2013).

4. Water temperature (T): In addition to its effect on sea level, evaporation rates, and precipitation, the predicted change in air temperature will be accompanied by changes in water temperature that in turn directly influence the habitat quality of Florida Bay. To capture this, we added a fourth variable, water temperature, to the scenarios outlined by (Obeysekera 2014). Because the FATHOM model does not reliably simulate water temperature, we instead derived temperature values corresponding to the FATHOM simulations from monthly measurements taken at stations within Florida Bay (Fig. 1, triangles within the Bay). These timeseries
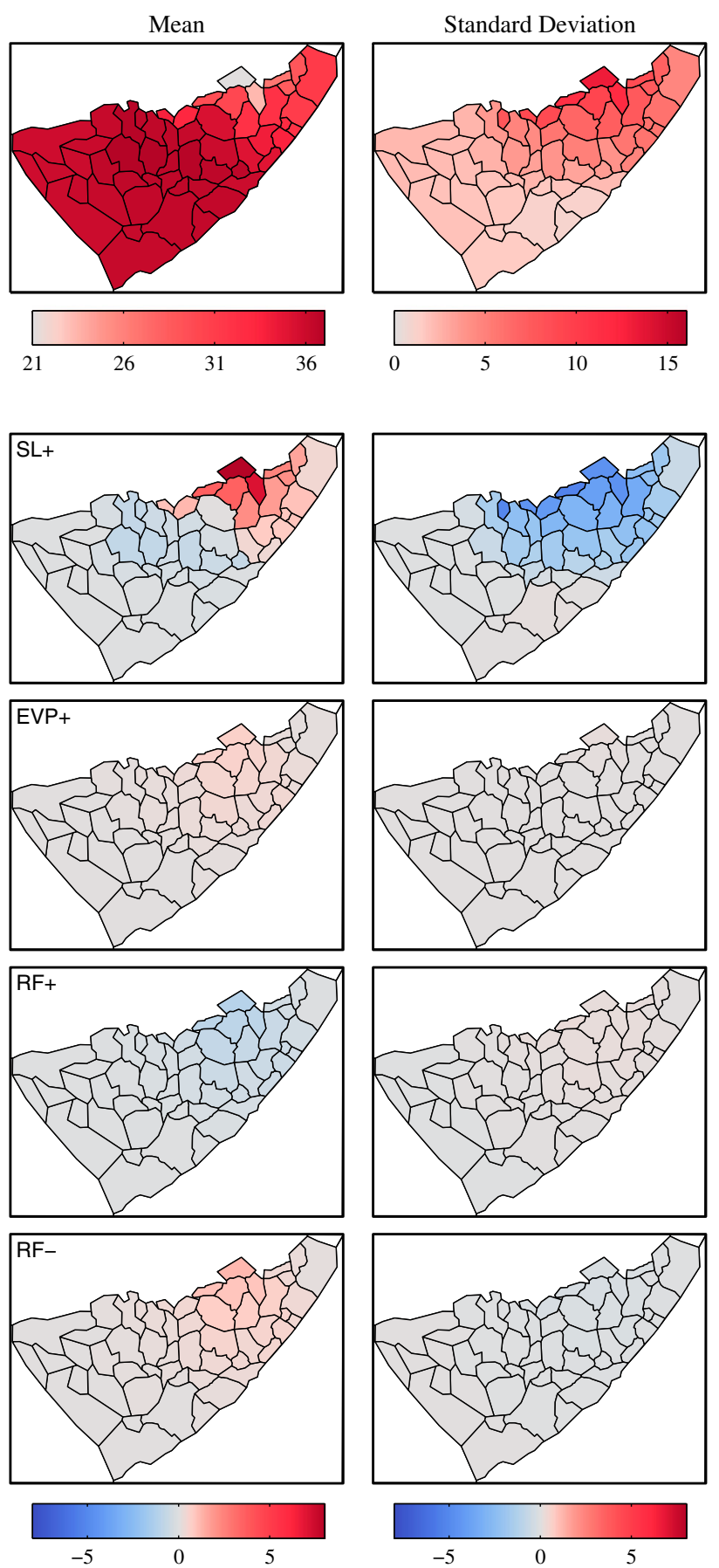

Fig. 2 Spatial change in salinity. The top two panels show the mean (left) and SD (right) of the baseline scenario. The remaining panels show the change in these properties that can be attributed to increased sea level, increased evaporation, and increased/decreased rainfall and runoff, derived by subtracting the results of scenarios that do and do not include the changes in each input variable

were available for the period of 1993-2005; for all missing years, we applied the monthly mean climatology values. Temperature varied little among the stations, so for the baseline case (T0), each model basin was simply assigned the timeseries corresponding to the 
Table 2 Salinity statistics

All statistics are calculated across time. For regions, values were first spatially averaged, weighting each contributing basin value by the area of the respective basin. Sparkline mini-plots show the relative trend across values in each row, normalized to the range of that row

\begin{tabular}{|c|c|c|c|c|c|c|c|}
\hline Basin & Statistic & Spa & $\begin{array}{r}\text { SL0 } \\
\text { EVPO } \\
\text { RF0 } \\
\text { T0 }\end{array}$ & $\begin{array}{r}\text { SL+ } \\
\text { EVPO } \\
\text { RFO } \\
\text { TO }\end{array}$ & $\begin{array}{r}\text { SL+ } \\
\text { EVP+ } \\
\text { RF0 } \\
\text { T0 }\end{array}$ & $\begin{array}{r}\text { SL+ } \\
\text { EVP+ } \\
\text { RF+ } \\
\text { T0 }\end{array}$ & $\begin{array}{r}\text { SL+ } \\
\text { EVP+ } \\
\text { RF- } \\
\text { T0 }\end{array}$ \\
\hline Florida Bay & $\begin{array}{l}\text { Mean } \\
\text { Median } \\
\text { Std. Dev. }\end{array}$ & & $\begin{array}{r}34.941 \\
34.991 \\
3.286\end{array}$ & $\begin{array}{r}35.284 \\
35.525 \\
2.421\end{array}$ & $\begin{array}{r}35.432 \\
35.688 \\
2.438\end{array}$ & $\begin{array}{r}35.210 \\
35.435 \\
2.480\end{array}$ & $\begin{array}{r}35.659 \\
35.936 \\
2.397\end{array}$ \\
\hline $\begin{array}{l}\text { Sampling re- } \\
\text { gion }\end{array}$ & $\begin{array}{l}\text { Mean } \\
\text { Median } \\
\text { Std. Dev. }\end{array}$ & & $\begin{array}{r}36.156 \\
\\
36.403 \\
2.834\end{array}$ & $\begin{array}{r}36.137 \\
2.168\end{array}$ & $\begin{array}{r}36.213 \\
2.176\end{array}$ & $\begin{array}{r}36.102 \\
2.192\end{array}$ & $\begin{array}{r}36.123 \\
\\
36.343 \\
2.162\end{array}$ \\
\hline West & $\begin{array}{l}\text { Mean } \\
\text { Median } \\
\text { Std. Dev. }\end{array}$ & & $\begin{array}{r}36.263 \\
36.438 \\
2.090\end{array}$ & $\begin{array}{r}36.085 \\
36.295 \\
1.829\end{array}$ & $\begin{array}{r}36.163 \\
36.370 \\
1.836\end{array}$ & $\begin{array}{r}36.055 \\
36.253 \\
1.849\end{array}$ & $\begin{array}{r}36.271 \\
36.513 \\
1.824\end{array}$ \\
\hline East inshore & $\begin{array}{l}\text { Mean } \\
\text { Median } \\
\text { Std. Dev. }\end{array}$ & & $\begin{array}{l}25.587 \\
25.358 \\
10.118\end{array}$ & $\begin{array}{r}30.469 \\
31.220 \\
6.598\end{array}$ & $\begin{array}{r}30.868 \\
31.592 \\
6.682\end{array}$ & $\begin{array}{r}30.166 \\
30.910 \\
6.826\end{array}$ & $\begin{array}{r}31.597 \\
32.326 \\
6.526\end{array}$ \\
\hline West inshore & $\begin{array}{l}\text { Mean } \\
\text { Median } \\
\text { Std. Dev. }\end{array}$ & & $\begin{array}{r}35.452 \\
36.155 \\
6.507\end{array}$ & $\begin{array}{r}35.482 \\
35.886 \\
3.204\end{array}$ & $\begin{array}{r}35.688 \\
36.081 \\
3.223\end{array}$ & $\begin{array}{r}35.378 \\
35.819 \\
3.348\end{array}$ & $\begin{array}{r}36.001 \\
36.397 \\
3.098\end{array}$ \\
\hline East & $\begin{array}{l}\text { Mean } \\
\text { Median } \\
\text { Std. Dev. }\end{array}$ & & $\begin{array}{r}32.446 \\
32.483 \\
6.182\end{array}$ & $\begin{array}{r}33.565 \\
33.869 \\
4.017\end{array}$ & $\begin{array}{r}33.893 \\
34.189 \\
4.057\end{array}$ & $\begin{array}{r}33.392 \\
33.649 \\
4.172\end{array}$ & $\begin{array}{r}34.406 \\
34.662 \\
3.940\end{array}$ \\
\hline
\end{tabular}

juvenile and small adult fish community (Thayer et al. 1999). The otter trawls consist of a net with $6 \mathrm{~mm}$ mesh in the net body and $3 \mathrm{~mm}$ mesh in the tail bag. The field data span the years of 2004-2012, and were conducted monthly from June through November of each year.

These tows were conducted using a stratified random sampling design. The sampling area was first divided into four sub-regions: West, (approximately FATHOM basins 58, 42, 57, 39, 56, 40, and 41, see Fig. 1), Rankin (basins 55, 37, and 36), Whipray (basins basins 34 and 35), and Crocodile Dragover (basins 23, 24, 25, and 26). Each subregion was divided into macrocells that are $1,800 \mathrm{~m}$ on each side; this results in 50 macrocells in West, 23 in Rankin, 19 in Whipray, and 20 in Crocodile Dragover. Each macrocell was then further divided into 4 microcells that measured $900 \mathrm{~m}$ on each side. First, the macrocells to be sampled within a sub-region were randomly selected, and then within each macrocell a random microcell was selected to conduct the otter trawl. From 2004 through 2008, sixty otter trawls were conducted each month; 26 stations were sampled in West, 14 in Rankin, 10 in Whipray, and 10 in Crocodile Dragover. After 2008, the sampling design was modified based upon a power analysis. The new sample design samples all of the macrocells in Rankin, Whipray, and Crocodile Dragover, and 20 randomly selected stations in West each month. For both periods, a random microcell was sampled at each macrocell sample location. 
Table 3 Habitat suitability model details for the six juvenile fish species

\begin{tabular}{|c|c|c|c|}
\hline Coefficient & Estimate & SE & $P$ value \\
\hline \multicolumn{4}{|c|}{ Spotted Seatrout $<100 \mathrm{~mm}$} \\
\hline \multicolumn{4}{|c|}{$\operatorname{logit}(H)=x_{1}+x_{2} S_{\mathrm{m}}+x_{3} A+x_{4} S_{\mathrm{a}} T_{\mathrm{a}}+x_{5} S_{\mathrm{a}}^{2}+x_{6} T_{\mathrm{a}}^{2}+x_{7} A^{2}$} \\
\hline$x_{1}$ & -69.92 & 13.57 & $2.59 \mathrm{e}-07$ \\
\hline$x_{2}$ & 0.1837 & 0.06147 & 0.002812 \\
\hline$x_{3}$ & 0.01749 & 0.006083 & 0.004039 \\
\hline$x_{4}$ & -0.04256 & 0.01394 & 0.002262 \\
\hline$x_{5}$ & 0.01716 & 0.002759 & $4.922 \mathrm{e}-10$ \\
\hline$x_{6}$ & -0.0604 & 0.0207 & 0.003517 \\
\hline$x_{7}$ & $-3.276 \mathrm{e}-05$ & $9.227 \mathrm{e}-06$ & 0.0003851 \\
\hline \multicolumn{4}{|c|}{ Gray Snapper } \\
\hline \multicolumn{4}{|c|}{$\operatorname{logit}(H)=x_{1}+x_{2} T_{\mathrm{a}}+x_{3} S_{\mathrm{a}} A+x_{4} S_{\mathrm{m}} A+x_{5} S_{\mathrm{m}}^{2}+x_{6} T_{\mathrm{a}}^{2}+x_{7} A^{2}$} \\
\hline$x_{1}$ & -34.69 & 10.72 & 0.001215 \\
\hline$x_{2}$ & 1.415 & 0.697 & 0.04236 \\
\hline$x_{3}$ & 0.001165 & 0.0005359 & 0.02976 \\
\hline$x_{4}$ & -0.001228 & 0.0004758 & 0.009881 \\
\hline$x_{5}$ & -0.006708 & 0.002141 & 0.001726 \\
\hline$x_{6}$ & -0.02531 & 0.01248 & 0.04253 \\
\hline$x_{7}$ & $-8.517 \mathrm{e}-06$ & $5.591 \mathrm{e}-06$ & 0.1277 \\
\hline \multicolumn{4}{|c|}{ Goldspotted Killifish } \\
\hline \multicolumn{4}{|c|}{$\operatorname{logit}(H)=x_{1}+x_{2} S_{\mathrm{a}}+x_{3} S_{\mathrm{m}}+x_{4} T_{\mathrm{a}} A+x_{5} S_{\mathrm{m}}^{2}$} \\
\hline$x_{1}$ & 5.309 & 27.67 & 0.8479 \\
\hline$x_{2}$ & 2.997 & 0.6565 & $5.002 \mathrm{e}-06$ \\
\hline$x_{3}$ & 1.64 & 1.019 & 0.1074 \\
\hline$x_{4}$ & 0.008947 & 0.002561 & 0.0004771 \\
\hline$x_{5}$ & -0.04311 & 0.01282 & 0.0007706 \\
\hline \multicolumn{4}{|c|}{ Rainwater Killifish } \\
\hline \multicolumn{4}{|c|}{$\operatorname{logit}(H)=x_{1}+x_{2} S_{\mathrm{a}}+x_{3} T_{\mathrm{a}}+x_{4} A+x_{5} S_{\mathrm{a}}^{2}+x_{6} T_{\mathrm{a}}^{2}+x_{7} A^{2}$} \\
\hline$x_{1}$ & 30.34 & 26.46 & 0.2515 \\
\hline$x_{2}$ & 1.809 & 0.7788 & 0.0202 \\
\hline$x_{3}$ & -4.14 & 2.108 & 0.04959 \\
\hline$x_{4}$ & -0.04143 & 0.01895 & 0.02885 \\
\hline$x_{5}$ & -0.02177 & 0.009183 & 0.01777 \\
\hline$x_{6}$ & 0.07404 & 0.03754 & 0.04855 \\
\hline$x_{7}$ & $4.204 \mathrm{e}-05$ & $2.221 \mathrm{e}-05$ & 0.05836 \\
\hline \multicolumn{4}{|l|}{ Mojarra } \\
\hline \multicolumn{4}{|c|}{$\operatorname{logit}(H)=x_{1}+x_{2} S_{\mathrm{a}}+x_{3} S_{\mathrm{m}} T_{\mathrm{a}}$} \\
\hline$x_{1}$ & 194.1 & 87.4 & 0.02638 \\
\hline$x_{2}$ & 0.7187 & 0.3172 & 0.02347 \\
\hline$x_{3}$ & 0.1634 & 0.07334 & 0.02583 \\
\hline \multicolumn{4}{|l|}{ Pinfish } \\
\hline \multicolumn{4}{|c|}{$\operatorname{logit}(H)=x_{1}+x_{2} S_{\mathrm{a}}+x_{3} S_{\mathrm{m}}+x_{4} T_{\mathrm{a}} A+x_{5} S_{\mathrm{m}}^{2}+x_{6} A^{2}$} \\
\hline$x_{1}$ & -20.07 & 21.64 & 0.3538 \\
\hline$x_{2}$ & 0.7782 & 0.2454 & 0.001517 \\
\hline$x_{3}$ & 3.5 & 0.7857 & $8.387 e-06$ \\
\hline$x_{4}$ & 0.003645 & 0.001906 & 0.05583 \\
\hline$x_{5}$ & -0.04563 & 0.009916 & $4.196 \mathrm{e}-06$ \\
\hline$x_{6}$ & $9.461 \mathrm{e}-05$ & $3.796 e-05$ & 0.0127 \\
\hline
\end{tabular}

All equations are written in terms of the logit function, such that the HSI value $(H)$ is equal to $\frac{\exp (\operatorname{logit}(H))}{1+\exp (\operatorname{logit}(H))}$. The tables list the coefficient estimates, standard error of the coefficient estimates, and $P$ values for the $t$ statistic of each coefficient. The predictor variables include monthly-averaged salinity $\left(S_{\mathrm{a}}\right)$, monthly-maximum salinity $\left(S_{\mathrm{m}}\right)$, monthly-averaged water column temperature $\left(T_{\mathrm{a}}\right.$, in $\left.{ }^{\circ} \mathrm{C}\right)$, and sampling area $\left(A\right.$, in $\left.\mathrm{m}^{2}\right)$
Fig. 3 Slices of each HSI function are shown, versus each predictor variable included in the models. The HSI predictions themselves are shown in black, with the shaded gray region depicting the $95 \%$ confidence interval for the predictions. The outlined histograms indicate the distributions of each property associated with the juvenile fish sample counts, across all samples (blue) and just samples where the particular species was observed (red); both are normalized to the maximum all-observations value. The dotted black line indicates the mean value of each predictor variable in the observation dataset; for each slice, this indicates the value where the other predictor variables are set (e.g., the average salinity vs. HSI curve shows the predictions and confidence intervals when maximum salinity, average temperature, and sampling area are set to their mean-observed values)

Environmental conditions, including temperature and salinity at time of sampling, were measured alongside the trawl data. However, because the FATHOM model resolves its output as monthly statistical values rather than instantaneous values, we wanted to build our habitat suitability models using comparable environmental data. Under the Everglades National Park Marine Monitoring Network, salinity and temperature data have been measured at approximately 1-h resolution at 22 stations around Florida Bay (Fig. 1). We interpolated these timeseries to the locations of the juvenile fish collection stations using inverse distance weighting interpolation (see supplementary methods for full details). Using the resulting interpolated timeseries, we then calculated a variety of statistics on the 30-day section preceding each observation, including average salinity, average temperature, and maximum salinity values.

Of the 95 juvenile fish species quantified in the trawl surveys, we chose to focus on six for our habitat suitability models (Table 1). These include two major recreational fisheries target species: spotted seatrout (Cynoscion nebulosus) and gray snapper (Lutjanus griseus), as well as four of their most common prey species: goldspotted killifish (Floridichthys carpio), rainwater killifish (Lucania parva), mojarra (Eucinostomus spp.), and pinfish (Lagodon rhomboides). The seatrout and snapper were quantified as either present or absent for all trawls in the dataset, totaling 3615 observation points each. The four remaining species were only quantified at a subset of approximately 12 stations each month from 2009 through 2012, resulting in only 297 data points each. Logistic regression models were fit to the presence/absence data for each species, using average salinity, maximum salinity, and average temperature as potential predictor variables. Because there was some variation in the exact area covered by each trawl, we also included sampling (i.e., trawl) area as a predictor variable to eliminate any trends associated with this variable. Stepwise regression was performed on each species dataset using a Generalized Linear Model with logit link function, allowing for inclusion of linear, quadratic, and paired 

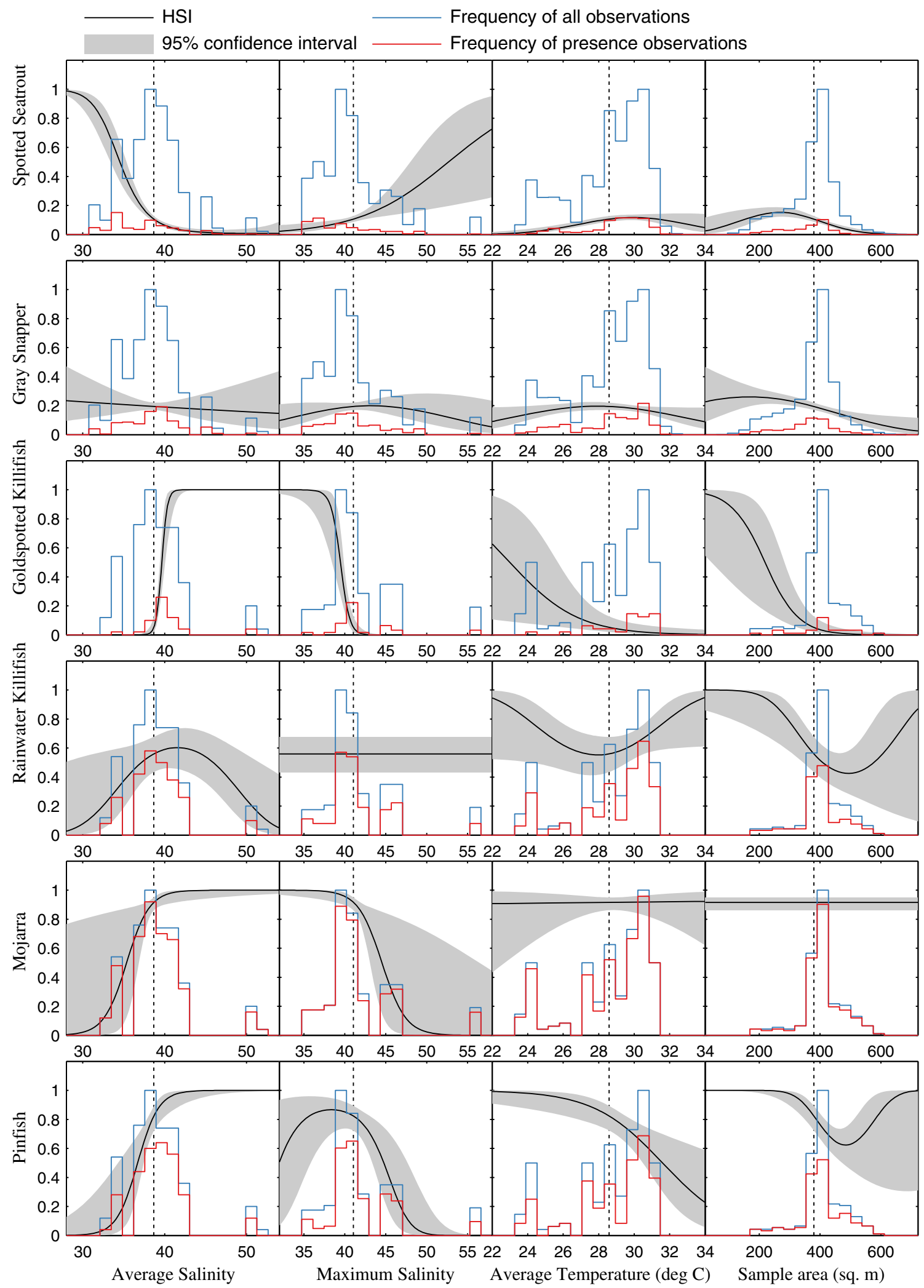
product interaction terms. Terms were added or removed using the criterion that a term must decrease the Akaike information criterion (AIC) of the model in order to be included. The resulting logistic regression models calculate the probability of observing a particular fish species under the given conditions; we will refer to this quantity as the HSI value.

The resulting HSI models were mapped onto each climate change scenario using the FATHOM monthly-average and monthly-maximum salinity values for each basin coupled with the water temperature timeseries described in the section "Modeling the Physical Effects of Climate Change Scenarios on Florida Bay." The sampling area variable of each HSI equation was set to $400 \mathrm{~m}^{2}$, the approximate mean for the observation dataset, for all simulations, so the HSI values can be interpreted as the probability of finding a given species in a $400 \mathrm{~m}^{2}$ portion of a basin.

Juvenile fish are not typically found in the more eastern portions of Florida Bay, due to the lack of seagrass cover in this portion of the Bay. Therefore, extrapolating the HSI predictions beyond the basins from which the observations were gathered should be done cautiously. In this study, we have applied the models to the entire bay, but have focused our analysis and conclusions on the 16 basins from which data were collected, hereafter referred to as the sampling region (Fig. 1, black line).

\section{Survival Models for Juvenile Lobster}

Caribbean spiny lobsters are tropical marine organisms whose tolerance to the fluctuating temperatures and salinities found in estuaries is limited, particularly among the vulnerable early life history stages that occur in hardbottom nursery areas within Florida Bay. Laboratory studies using temperatures between 18 and $32{ }^{\circ} \mathrm{C}$ and salinities ranging from 25 to 50 psu indicate that postlarval and early benthic juvenile lobsters experience high mortality at salinities much different from seawater, especially at high summer temperatures (Field and Butler 1994). Large juvenile adult lobster life stages, which are less abundant in the Florida Bay nursery, tolerate a wider range of salinities and temperatures, but also respond to changes in environmental conditions by emigrating from the area (Herrnkind et al. 1997; Butler 2009). Postlarval lobsters also avoid water masses of low ( $<30 \mathrm{psu})$ or high $(>45 \mathrm{psu})$ salinity during

Table 4 HSI statistics for Spotted Seatrout

\begin{tabular}{|c|c|c|c|c|c|c|c|c|c|c|c|c|}
\hline \multirow[t]{4}{*}{ Basin } & Statistic & Sparkline & SLO & $\mathrm{SL}+$ & $\mathrm{SL}+$ & $\mathrm{SL}+$ & $\mathrm{SL}+$ & SLO & SL+ & SL+ & $\mathrm{SL}^{+}$ & SL+ \\
\hline & & & EVPO & EVPO & EVP+ & EVP+ & EVP+ & EVPO & EVPO & EVP+ & EVP+ & EVP+ \\
\hline & & & RFO & RFO & RFO & $\mathrm{RF}+$ & $\mathrm{RF}-$ & RFO & RFO & RFO & $\mathrm{RF}+$ & $\mathrm{RF}-$ \\
\hline & & & T0 & T0 & TO & T0 & TO & $\mathrm{T}+$ & $\mathrm{T}+$ & $\mathrm{T}+$ & $\mathrm{T}+$ & $\mathrm{T}+$ \\
\hline \multirow{3}{*}{$\begin{array}{l}\text { Florida } \\
\text { Bay }\end{array}$} & Mean & & 0.164 & 0.136 & 0.131 & 0.141 & 0.121 & 0.184 & 0.154 & 0.149 & 0.160 & 0.138 \\
\hline & is & & 0.106 & 0.074 & 071 & 0.079 & 0.067 & 0.128 & 0.100 & 0.094 & 0.103 & 0.088 \\
\hline & $\mathrm{S}$ & & 0.166 & 0.150 & 0.145 & 0.155 & 0.135 & 0.172 & 0.157 & 0.152 & 0.162 & 0.143 \\
\hline \multirow{3}{*}{$\begin{array}{l}\text { Sampling } \\
\text { region }\end{array}$} & Mean & & 0.128 & 0.105 & 0.102 & 0.108 & 0.097 & 0.143 & 0.119 & 0.116 & 0.123 & 0.110 \\
\hline & 10 & & 0.059 & 0.052 & 0.051 & 0.053 & 0.050 & 0.069 & 0.069 & 0.067 & 0.071 & 0.066 \\
\hline & ev. & & 0.157 & 0.128 & 0.125 & 0.131 & 0.118 & 0.166 & 0.137 & 0.135 & 0.141 & 0.128 \\
\hline \multirow[t]{3}{*}{ West } & 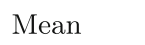 & & 0.091 & 0.085 & 0.083 & 0.087 & 0.078 & 0.105 & 0.098 & 0.095 & 0.100 & 0.090 \\
\hline & & & 0.051 & 0.046 & 0.045 & 0.046 & 0.044 & 0.063 & 0.064 & 0.063 & 0.063 & 0.061 \\
\hline & Std. Dev. & & 0.110 & 0.098 & 0.096 & 0.102 & 0.090 & 0.119 & 0.107 & 0.104 & 0.110 & 0.098 \\
\hline \multirow{3}{*}{$\begin{array}{l}\text { East in- } \\
\text { shore }\end{array}$} & Mean & & 0.553 & 0.407 & 0.395 & 0.419 & 0.369 & 0.591 & 0.445 & 0.432 & 0.456 & 0.404 \\
\hline & $\mathrm{M}$ & & 0.632 & 0.239 & 0.216 & 0.261 & 0.180 & 0.693 & 0.331 & 0.302 & 0.375 & 0.252 \\
\hline & Std & & 0.405 & 0.405 & 0.400 & 0.409 & 0.389 & 0.395 & 0.406 & 0.403 & 0.410 & 0.392 \\
\hline \multirow{3}{*}{$\begin{array}{l}\text { West in- } \\
\text { shore }\end{array}$} & Mean & & 0.272 & 0.187 & 0.179 & 0.196 & 0.163 & 0.289 & 0.202 & 0.194 & 0.212 & 0.176 \\
\hline & Media & & 0.056 & 0.066 & 0.061 & 0.065 & 0.057 & 0.080 & 0.074 & 0.068 & 0.077 & 0.061 \\
\hline & Std. Dev. & & 0.337 & 0.248 & 0.242 & 0.258 & 0.225 & 0.343 & 0.254 & 0.248 & 0.264 & 0.231 \\
\hline \multirow[t]{3}{*}{ East } & 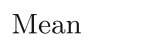 & & 0.305 & 0.241 & 0.228 & 0.252 & 0.205 & 0.345 & 0.275 & 0.260 & 0.287 & 0.234 \\
\hline & & & 0.120 & 0.095 & 0.087 & 0.100 & 0.080 & 0.183 & 0.132 & 0.122 & 0.138 & 0.111 \\
\hline & Dev. & & 0.338 & 0.289 & 0.278 & 0.300 & 0.254 & 0.347 & 0.301 & 0.291 & 0.313 & 0.267 \\
\hline
\end{tabular}

All statistics are calculated across time. For regions, values were first spatially averaged, weighting each contributing basin value by the area of the respective basin. Sparkline mini-plots show the relative trend across values in each row, normalized to the range of that row 
Table 5 HSI statistics for Gray Snapper

\begin{tabular}{|c|c|c|c|c|c|c|c|c|c|c|c|c|}
\hline \multirow[t]{4}{*}{ Basin } & Statistic & 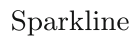 & SLO & $\mathrm{SL}+$ & SL+ & $\mathrm{SL}^{+}$ & $\mathrm{SL}+$ & SLO & SL+ & SL+ & $\mathrm{SL}+$ & SL+ \\
\hline & & & EVPO & EVPO & EVP+ & EVP+ & EVP+ & EVPO & EVPO & EVP+ & EVP+ & EVP+ \\
\hline & & & RFO & RFO & RFO & $\mathrm{RF}^{+}$ & $\mathrm{RF}-$ & RFO & RFO & RFO & $\mathrm{RF}+$ & $\mathrm{RF}-$ \\
\hline & & & TO & TO & TO & TO & TO & $\mathrm{T}+$ & $\mathrm{T}+$ & $\mathrm{T}+$ & $\mathrm{T}+$ & $\mathrm{T}+$ \\
\hline \multirow{3}{*}{$\begin{array}{l}\text { Florida } \\
\text { Bay }\end{array}$} & Mean & & 0.111 & 0.114 & 0.115 & 0.113 & 0.116 & 0.113 & 0.116 & 0.117 & 0.116 & 0.119 \\
\hline & edian & & 0.118 & 0.122 & 0.123 & 0.121 & 0.125 & 0.114 & 0.117 & 0.118 & 0.116 & 0.120 \\
\hline & ev. & & 0.040 & 0.040 & 0.040 & 0.040 & 0.040 & 0.034 & 0.033 & 0.033 & 0.033 & 0.033 \\
\hline \multirow{3}{*}{$\begin{array}{l}\text { Sampling } \\
\text { region }\end{array}$} & Mean & & 0.119 & 0.119 & 0.119 & 0.119 & 0.120 & 0.121 & 0.121 & 0.122 & 0.121 & 0.122 \\
\hline & Medi & & 0.128 & 0.130 & 0.131 & 0.130 & 0.131 & 0.122 & 0.124 & 0.125 & 0.124 & 0.126 \\
\hline & Std. Dev. & & 0.039 & 0.040 & 0.040 & 0.040 & 0.040 & 0.032 & 0.033 & 0.033 & 0.033 & 0.033 \\
\hline \multirow[t]{3}{*}{ West } & Mean & & 0.120 & 0.119 & 0.120 & 0.119 & 0.121 & 0.123 & 0.122 & 0.123 & 0.122 & 0.123 \\
\hline & Median & & 0.131 & 0.131 & 0.132 & 0.131 & 0.132 & 0.126 & 0.126 & 0.127 & 0.126 & 0.128 \\
\hline & Std. Dev. & & 0.040 & 0.040 & 0.040 & 0.040 & 0.041 & 0.033 & 0.032 & 0.033 & 0.033 & 0.033 \\
\hline \multirow{3}{*}{$\begin{array}{l}\text { East in- } \\
\text { shore }\end{array}$} & Mean & & 0.059 & 0.082 & 0.084 & 0.080 & 0.088 & 0.061 & 0.085 & 0.087 & 0.083 & 0.091 \\
\hline & $\mathrm{Med}$ & & 0.046 & 0.078 & 0.081 & 0.074 & 0.088 & 0.046 & 0.081 & 0.085 & 0.078 & 0.091 \\
\hline & Std. Dev. & & 0.051 & 0.050 & 0.050 & 0.051 & 0.050 & 0.052 & 0.050 & 0.050 & 0.050 & 0.048 \\
\hline \multirow{3}{*}{$\begin{array}{l}\text { West in- } \\
\text { shore }\end{array}$} & Mean & & 0.110 & 0.118 & 0.119 & 0.117 & 0.121 & 0.112 & 0.119 & 0.120 & 0.118 & 0.122 \\
\hline & Med & & 0.113 & 0.121 & 0.123 & 0.121 & 0.125 & 0.111 & 0.116 & 0.117 & 0.116 & 0.120 \\
\hline & Std. Dev. & & 0.041 & 0.038 & 0.038 & 0.038 & 0.038 & 0.039 & 0.035 & 0.035 & 0.035 & 0.034 \\
\hline \multirow[t]{3}{*}{ East } & Mea & & 0.091 & 0.101 & 0.103 & 0.100 & 0.106 & 0.092 & 0.103 & 0.105 & 0.102 & 0.108 \\
\hline & & & 0.090 & 0.101 & 0.104 & 0.099 & 0.110 & 0.093 & 0.102 & 0.105 & 0.100 & 0.109 \\
\hline & Std. Dev. & & 0.049 & 0.044 & 0.044 & 0.045 & 0.044 & 0.047 & 0.040 & 0.040 & 0.041 & 0.039 \\
\hline
\end{tabular}

All statistics are calculated across time. For regions, values were first spatially averaged, weighting each contributing basin value by the area of the respective basin. Sparkline mini-plots show the relative trend across values in each row, normalized to the range of that row

their onshore migration from the open sea (Goldstein and Butler 2009). For our modeling analysis, we focused on the lethal effects of changing salinity and temperature on the survival of benthic juvenile lobsters in Florida Bay, rather than the sublethal effects on lobster emigration and growth that are not captured by our HSI modeling. Therefore, weekly survival data from Field and Butler (1994) were used to derive a function describing the monthly relationship of survival $\left(P_{\mathrm{s}}\right)$ to salinity $(S)$ and temperature $(T)$ :

$$
P_{\mathrm{S}}=123.6 \mathrm{e}^{-\frac{1}{2}\left(\left(\frac{T-24.39}{5.565}\right)^{2}+\left(\frac{S-3.31}{8.587}\right)^{2}\right)}
$$

We use this equation as our HSI model for juvenile lobster.

\section{Results}

\section{Salinity Under Changing Climate}

Modeled salinity values of basins in Florida Bay, when averaged over time across the entire 36-year timeseries of monthly mean output values for each individual basin, resulted in temporal mean values ranging from approximately 21.05 to $37.04 \mathrm{psu}$, with standard deviations over time ranging from 1.04 to $13.17 \mathrm{psu}$. To simplify the presentation of our results, we have categorized the basins into four groups: east, west, east inshore, and west inshore (see supplemental material for details of the clustering procedure). The western basins, which cover the most area of the four groups, are characterized by the highest mean salinity values (36.16 psu) and lowest temporal variability $\left(\sigma^{2}=2.09 \mathrm{psu}\right)$ under baseline conditions. The eastern basins are fresher and more variable than the western region, with a mean and SD of 32.45 and 6.18, respectively. The western inshore basins cluster around the mouth of McCormick Creek; they also have high mean salinity (35.45 psu), but higher temporal variability $\left(\sigma^{2}=6.51 \mathrm{psu}\right)$. Finally, the eastern inshore group is located closest to where Trout Creek and the Taylor River deliver the majority of the freshwater input to the estuary, and show the lowest mean (25.59 psu) and highest SD (10.12 psu) of all the regions under baseline conditions (Fig. 2).

Three of the variables manipulated by our climate change scenarios, including sea level (SL), evaporation rate (EVP), and rainfall/runoff (RF), affect the resulting salinity of 
Table 6 HSI statistics for Goldspotted Killifish

\begin{tabular}{|c|c|c|c|c|c|c|c|c|c|c|c|c|}
\hline \multirow[t]{4}{*}{ Basin } & Statistic & Prow & SLO & $\mathrm{SL}+$ & SL+ & $\mathrm{SL}+$ & SL+ & SLO & $\mathrm{SL}^{+}$ & $\mathrm{SL}^{+}$ & SL+ & SL+ \\
\hline & & & EVPO & EVPO & EVP+ & EVP+ & EVP+ & EVPO & EVPO & EVP+ & EVP+ & EVP+ \\
\hline & & & RFO & RFO & RFO & $\mathrm{RF}+$ & $\mathrm{RF}-$ & RFO & RFO & RFO & $\mathrm{RF}+$ & $\mathrm{RF}-$ \\
\hline & & & TO & TO & TO & TO & T0 & $\mathrm{T}+$ & $\mathrm{T}+$ & $\mathrm{T}+$ & $\mathrm{T}+$ & $\mathrm{T}+$ \\
\hline \multirow{3}{*}{$\begin{array}{l}\text { Florida } \\
\text { Bay }\end{array}$} & Mean & & 0.243 & 0.214 & 0.227 & 0.212 & 0.244 & 0.216 & 0.185 & 0.197 & 0.183 & 0.213 \\
\hline & dian & & 137 & 0.104 & 0.115 & 0.100 & 0.137 & 0.107 & 0.080 & 0.087 & 0.076 & 0.106 \\
\hline & ev. & & 0.259 & 0.245 & 0.253 & 0.245 & 0.259 & 0.243 & 0.226 & 0.234 & 0.226 & 0.241 \\
\hline \multirow{3}{*}{$\begin{array}{l}\text { Sampling } \\
\text { region }\end{array}$} & Mean & & 0.282 & 0.240 & 0.248 & 0.238 & 0.258 & 0.254 & 0.208 & 0.216 & 0.207 & 0.225 \\
\hline & $\mathrm{N}$ & & 167 & 0.117 & 127 & 17 & 0.141 & 0.129 & 0.090 & 096 & .088 & 0.107 \\
\hline & Std. Dev. & & 0.293 & 0.273 & 0.277 & 0.274 & 0.280 & 0.279 & 0.253 & 0.257 & 0.254 & 0.261 \\
\hline \multirow[t]{3}{*}{ West } & Mean & & 0.263 & 0.233 & 0.243 & 0.231 & 0.255 & 0.230 & 0.198 & 0.207 & 0.197 & 0.219 \\
\hline & dian & & 0.169 & 0.131 & 0.144 & 0.129 & 0.160 & 0.132 & 0.099 & 0.108 & 0.097 & 0.122 \\
\hline & Std. Dev. & & 0.267 & 0.253 & 0.258 & 0.253 & 0.261 & 0.248 & 0.230 & 0.236 & 0.231 & 0.240 \\
\hline \multirow{3}{*}{$\begin{array}{l}\text { East in- } \\
\text { shore }\end{array}$} & Mean & & 0.106 & 0.123 & 0.140 & 0.119 & 0.165 & 0.099 & 0.113 & 0.130 & 0.109 & 0.154 \\
\hline & $\mathrm{N}$ & & 0.000 & 0.000 & 0.000 & 0.000 & 0.001 & 0.000 & 0.000 & 0.000 & 0.000 & 0.001 \\
\hline & Std. Dev. & & 0.242 & 0.244 & 0.259 & 0.243 & 0.275 & 0.231 & 0.232 & 0.247 & 0.231 & 0.263 \\
\hline \multirow{3}{*}{$\begin{array}{l}\text { West in- } \\
\text { shore }\end{array}$} & Mean & & 0.335 & 0.259 & 0.278 & 0.257 & 0.301 & 0.320 & 0.234 & 0.253 & 0.233 & 0.274 \\
\hline & Med & & 0.052 & 0.041 & 0.054 & 0.038 & 0.080 & 0.038 & 0.030 & 0.039 & 0.027 & 0.058 \\
\hline & Std. Dev. & & 0.407 & 0.337 & 0.348 & 0.339 & 0.356 & 0.401 & 0.320 & 0.332 & 0.322 & 0.341 \\
\hline \multirow[t]{3}{*}{ East } & & & 0.181 & 0.158 & 0.180 & 0.154 & 0.212 & 0.171 & 0.144 & 0.165 & 0.140 & 0.195 \\
\hline & & & 0.003 & 0.008 & 0.016 & 0.006 & 0.038 & 0.002 & 0.006 & 0.011 & 0.004 & 0.028 \\
\hline & Std. Dev. & & 0.294 & 0.259 & 0.273 & 0.259 & 0.285 & 0.285 & 0.246 & 0.261 & 0.246 & 0.274 \\
\hline
\end{tabular}

All statistics are calculated across time. For regions, values were first spatially averaged, weighting each contributing basin value by the area of the respective basin. Sparkline mini-plots show the relative trend across values in each row, normalized to the range of that row

Florida Bay. Table 2 shows the temporal mean, median, and SD of salinity values in each basin group under each of the five scenarios that modify these three variables; the corresponding statistics for each individual basin can be found in the supplementary material, in Table S2. Increased sea level leads to increased mixing between basins and the coastal ocean, bringing the salinity of highly saline central basins down and that of the fresher eastern basins up; the net effect is a small increase $(+0.343$ psu mean, +0.534 psu median $)$ in the bay-wide spatially averaged salinity and a decrease in temporal variability. Bay-wide SD decreases from 3.28 to 2.42 psu under these conditions, primarily due to a decrease in the frequency and duration of low salinity events. The effects of increasing evaporation rate and decreasing rainfall on salinity are similar in direction to that of sea level rise, increasing the spatially averaged mean and decreasing spatially averaged variability, but the magnitude of these changes is much smaller than those induced by sea level rise.

Spatially, the salinity changes are concentrated in those basins located closer to the shore and, consequently, to the freshwater input locations. These basins show increases in temporal mean of 7-8 psu and decreases in temporal SD of 4-5 psu. However, the basins located in the western portion of the bay, which include the juvenile fish sampling region basins, show much smaller responses, with changes in mean and SD on the order of 0.1 psu or less.

\section{Habitat Change Under Changing Temperature and Salinity}

The final HSI model equations for each of the juvenile fish species are described in Table 3, with a visualization of the regression models and the underlying data available in Fig. 3.

The HSI values resulting when these equations, along with (1), are applied to the output of the 10 different FATHOM scenarios are presented in Tables S3 to S9 ; summary statistics for the basin groups are shown in Tables 4, 5, 6, 7, 8, 9 and 10 .

The climate scenarios led to relatively small changes in HSI values across the bay, particularly in the western basins, where the majority of the sampling region is located 
Table 7 HSI statistics for Rainwater Killifish

\begin{tabular}{|c|c|c|c|c|c|c|c|c|c|c|c|c|}
\hline \multirow[t]{4}{*}{ Basin } & Statistic & & SLO & SL+ & SL+ & $\mathrm{SL}+$ & SL+ & SLO & $\mathrm{SL}+$ & $\mathrm{SL}^{+}$ & SL+ & $\mathrm{SL}^{+}$ \\
\hline & & & EVPO & EVPO & EVP+ & EVP+ & EVP+ & EVPO & EVPO & EVP+ & EVP+ & EVP+ \\
\hline & & & RFO & RFO & RFO & $\mathrm{RF}+$ & $\mathrm{RF}-$ & RFO & RFO & RFO & $\mathrm{RF}^{+}$ & $\mathrm{RF}-$ \\
\hline & & & To & TO & TO & TO & TO & $\mathrm{T}+$ & $\mathrm{T}+$ & $\mathrm{T}+$ & $\mathrm{T}+$ & $\mathrm{T}+$ \\
\hline \multirow{3}{*}{$\begin{array}{l}\text { Florida } \\
\text { Bay }\end{array}$} & Mean & & 0.539 & 0.561 & 0.567 & 0.557 & 0.578 & 0.526 & 0.547 & 0.554 & 0.543 & 0.564 \\
\hline & & & 0.523 & 0.537 & 0.543 & 0.533 & 0.551 & 0.519 & 0.541 & 0.545 & 0.538 & 0.552 \\
\hline & ev. & & 0.210 & 0.214 & 0.213 & 0.216 & 0.209 & 0.186 & 0.188 & 0.187 & 0.189 & 0.185 \\
\hline \multirow{3}{*}{$\begin{array}{l}\text { Sampling } \\
\text { region }\end{array}$} & Mean & & 0.588 & 0.597 & 0.600 & 0.595 & 0.605 & 0.576 & 0.585 & 0.588 & 0.582 & 0.594 \\
\hline & $\mathrm{N}$ & & 0.575 & 0.576 & 0.580 & 0.577 & 0.586 & 0.561 & 0.573 & 0.579 & 0.569 & 0.586 \\
\hline & Std. & & 0.223 & 0.213 & 0.212 & 0.215 & 0.209 & 0.197 & 0.189 & 0.188 & 0.190 & 0.186 \\
\hline \multirow[t]{3}{*}{ West } & Mean & & 0.609 & 0.610 & 0.614 & 0.608 & 0.619 & 0.597 & 0.598 & 0.601 & 0.596 & 0.607 \\
\hline & Median & & 0.588 & 0.580 & 0.584 & 0.579 & 0.590 & 0.589 & 0.587 & 0.591 & 0.586 & 0.597 \\
\hline & Std. Dev. & & 0.206 & 0.204 & 0.203 & 0.205 & 0.200 & 0.182 & 0.180 & 0.179 & 0.181 & 0.177 \\
\hline \multirow{3}{*}{$\begin{array}{l}\text { East in- } \\
\text { shore }\end{array}$} & Mean & & 0.225 & 0.334 & 0.346 & 0.325 & 0.368 & 0.206 & 0.309 & 0.322 & 0.300 & 0.346 \\
\hline & $\mathrm{N}$ & & 0.087 & 0.263 & 0.294 & 0.248 & 0.341 & 0.091 & 0.265 & 0.294 & 0.252 & 0.340 \\
\hline & Dev. & & 0.275 & 0.311 & 0.313 & 0.312 & 0.312 & 0.253 & 0.280 & 0.282 & 0.280 & 0.282 \\
\hline \multirow{3}{*}{$\begin{array}{l}\text { West in- } \\
\text { shore }\end{array}$} & Mean & & 0.503 & 0.555 & 0.564 & 0.548 & 0.579 & 0.497 & 0.553 & 0.563 & 0.546 & 0.579 \\
\hline & Med & & 0.535 & 0.563 & 0.569 & 0.565 & 0.578 & 0.535 & 0.560 & 0.572 & 0.554 & 0.588 \\
\hline & Std. Dev. & & 0.297 & 0.247 & 0.245 & 0.253 & 0.236 & 0.275 & 0.223 & 0.221 & 0.228 & 0.214 \\
\hline \multirow[t]{3}{*}{ East } & Mean & & 0.371 & 0.442 & 0.457 & 0.433 & 0.480 & 0.355 & 0.423 & 0.439 & 0.414 & 0.463 \\
\hline & & & 0.362 & 0.443 & 0.459 & 0.435 & 0.490 & 0.357 & 0.447 & 0.468 & 0.440 & 0.491 \\
\hline & Std. Dev. & & 0.279 & 0.273 & 0.270 & 0.277 & 0.261 & 0.262 & 0.247 & 0.245 & 0.251 & 0.237 \\
\hline
\end{tabular}

All statistics are calculated across time. For regions, values were first spatially averaged, weighting each contributing basin value by the area of the respective basin. Sparkline mini-plots show the relative trend across values in each row, normalized to the range of that row

(Figs. 4, 5). Because the absolute changes are small, and the HSI ranges vary widely between species, we chose to quantify some of our analysis in terms of quantile values based on the baseline conditions in the sampling region. Cumulative distribution functions of area vs HSI value were calculated across all baseline output values (i.e., 432 time steps and 16 sampling basins) and then divided into quartiles. For the remainder of this paper, these quartile intervals will be used to define poor (first quartile), fair (second quartile), good (third quartile), and optimal (upper quartile) habitat.

The effect of the climate scenarios varied in both magnitude and direction across the seven species (Table 11; Fig. 6). Within the samping region, optimal habitat for spotted seatrout is predicted to decrease under the salinity-altered-only scenarios but increased under the temperature-altered-only scenario, with the combined effect leading to a decrease of $-4.58 \mathrm{~km}^{2}$ (3.4\% change). The mojarra also saw opposite effects from salinity and temperature, with the salinity alterations leading to an increase in optimal habitat and the temperature increase leading to a decrease. Like the seatrout, the combined effect resulted in a decrease in optimal habitat for mojarra. Juvenile lobster benefited most strongly of all the species from the changing salinity characteristics; lobsters are predicted to experience a small decrease in optimal habitat under the temperature only scenario, but an increase of at least $20 \mathrm{~km}^{2}$ (a 10-13\% increase) in all other scenarios. Gray snapper may see only a small decrease in optimal habitat as a result of salinity alterations, but lose between 15.4 and $16.99 \mathrm{~km}^{2}$ under the temperature-altering scenarios. The remaining species (goldspotted killifish, rainwater killifish, and pinfish) lose optimal habitat as a result of both the salinity and temperature alterations.

We also examined the shifts in seasonal habitat availability under various scenarios. Figure 7 depicts the quartile distribution, averaged over each month, under the scenarios that provided the best (i.e., largest increase or smallest decrease in yearly-averaged optimal habitat area) and worst (i.e., largest decrease or smallest increase in optimal habitat) scenario.

The juvenile fish sampling design aims to effectively sample the period of the year with optimal abundances of juvenile spotted seatrout, which are typically found from 
Table 8 HSI statistics for Mojarra

\begin{tabular}{|c|c|c|c|c|c|c|c|c|c|c|c|c|}
\hline \multirow[t]{4}{*}{ Basin } & Statistic & Sparkline & SLO & SL+ & SL+ & $\mathrm{SL}+$ & SL+ & SLO & $\mathrm{SL}^{+}$ & $\mathrm{SL}^{+}$ & SL+ & $\mathrm{SL}^{+}$ \\
\hline & & & EVPO & EVPO & EVP+ & EVP+ & EVP+ & EVPO & EVPO & EVP+ & EVP+ & EVP+ \\
\hline & & & RFO & RFO & RFO & $\mathrm{RF}+$ & $\mathrm{RF}-$ & RFO & RFO & RFO & $\mathrm{RF}+$ & $\mathrm{RF}-$ \\
\hline & & & TO & TO & TO & TO & T0 & $\mathrm{T}+$ & $\mathrm{T}+$ & $\mathrm{T}+$ & $\mathrm{T}+$ & $\mathrm{T}+$ \\
\hline \multirow{3}{*}{$\begin{array}{l}\text { Florida } \\
\text { Bay }\end{array}$} & Mean & & 0.918 & 0.939 & 0.941 & 0.936 & 0.945 & 0.884 & 0.900 & 0.904 & 0.897 & 0.911 \\
\hline & dian & & 0.977 & 0.990 & 0.989 & 0.990 & 0.988 & 0.967 & 0.981 & 0.979 & 0.980 & 0.979 \\
\hline & ev. & & 0.116 & 0.097 & 0.093 & 0.101 & 0.085 & 0.164 & 0.151 & 0.145 & 0.155 & 0.135 \\
\hline \multirow{3}{*}{$\begin{array}{l}\text { Sampling } \\
\text { region }\end{array}$} & Mean & & 0.917 & 0.949 & 0.950 & 0.947 & 0.953 & 0.889 & 0.916 & 0.918 & 0.913 & 0.923 \\
\hline & $\mathrm{N}$ & & 0.964 & 0.990 & 0.990 & 0.990 & 0.990 & 0.960 & 0.984 & 985 & .984 & .985 \\
\hline & & & 0.108 & 0.081 & 0.079 & 0.084 & 0.074 & 0.151 & 0.131 & 0.128 & 0.135 & 0.121 \\
\hline \multirow[t]{3}{*}{ West } & Mean & & 0.958 & 0.965 & 0.966 & 0.964 & 0.968 & 0.930 & 0.936 & 0.938 & 0.934 & 0.942 \\
\hline & $\mathrm{N}$ & & 0.986 & 0.993 & 0.993 & 0.993 & 0.992 & 0.979 & 0.987 & 0.987 & 0.987 & 0.987 \\
\hline & Std. Dev. & & 0.064 & 0.055 & 0.053 & 0.057 & 0.049 & 0.110 & 0.102 & 0.098 & 0.105 & 0.092 \\
\hline \multirow{3}{*}{$\begin{array}{l}\text { East in- } \\
\text { shore }\end{array}$} & Mean & & 0.705 & 0.788 & 0.791 & 0.780 & 0.803 & 0.661 & 0.726 & 0.732 & 0.720 & 0.745 \\
\hline & $\mathrm{N}$ & & 0.965 & 0.982 & 0.977 & 0.981 & 0.975 & 0.914 & 0.965 & 0.962 & 0.962 & 0.960 \\
\hline & & & 0.390 & 0.330 & 0.323 & 0.338 & 0.307 & 0.415 & 0.384 & 0.378 & 0.390 & 0.364 \\
\hline \multirow{3}{*}{$\begin{array}{l}\text { West in- } \\
\text { shore }\end{array}$} & Mean & & 0.753 & 0.875 & 0.879 & 0.868 & 0.890 & 0.726 & 0.824 & 0.831 & 0.816 & 0.845 \\
\hline & $\mathrm{N}$ & & 0.886 & 0.982 & 0.980 & 0.980 & 0.980 & 0.877 & 0.975 & 0.975 & 0.974 & 0.976 \\
\hline & Std. Dev. & & 0.297 & 0.211 & 0.205 & 0.220 & 0.190 & 0.327 & 0.268 & 0.261 & 0.277 & 0.245 \\
\hline \multirow[t]{3}{*}{ East } & Mean & & 0.867 & 0.899 & 0.904 & 0.893 & 0.914 & 0.809 & 0.834 & 0.842 & 0.826 & 0.858 \\
\hline & & & 0.982 & 0.990 & 0.988 & 0.989 & 0.987 & 0.969 & 0.979 & 0.976 & 0.978 & 0.977 \\
\hline & Std. Dev. & & 0.228 & 0.181 & 0.173 & 0.191 & 0.154 & 0.300 & 0.267 & 0.256 & 0.278 & 0.233 \\
\hline
\end{tabular}

All statistics are calculated across time. For regions, values were first spatially averaged, weighting each contributing basin value by the area of the respective basin. Sparkline mini-plots show the relative trend across values in each row, normalized to the range of that row

May through October (Kelble et al. 2013a). Despite this weakness, the HSIs predicted seasonal peaks in habitat quality that correlated well with observational data for spotted seatrout, snapper, mojarra, and pinfish throughout Florida Bay (Powell et al. 2007). The HSI models were not as good at reproducing seasonal distributions of rainwater killifish and goldspotted killifish. In the case of goldspotted killifish, this weakness could result from the model being parameterized with data from west and north-central Florida Bay, whereas the peak densities of gold spotted killifish are observed in northeastern Florida Bay.

The climate change scenarios resulted in an extension of the seasonal distributions of good habitat for gray snapper and spotted seatrout. However, these benefits will only be realized by the populations of gray snapper and spotted seatrout if their spawning season encompasses these months in which habitat suitability improved. For spotted seatrout, spawning occurs from March through October in Florida Bay, and there is a sufficient density of larval spotted seatrout under current conditions for the improvements in habitat suitability predicted in April and November to likely result in an increase in the population (Powell 2003). Spawning habits of the other species are not well-documented enough in Florida Bay to enable insights into whether the changes in habitat quality predicted under climate change would also require a change in spawning patterns to allow for juveniles to be present in the system when habitat conditions are optimal.

\section{Discussion}

The practice of adaptive management calls for managers to rely on science to reduce uncertainty, and thus provide alternative management strategies with reduced variability. Yet, some problems, such as that of managing ecosystem resources under changing climate conditions, are often left unexplored due to the inherent high uncertainties. Conditions that may emerge under a changing climate provide a suite of ambiguities that have been difficult to integrate into existing terrestrial, coastal, and marine planning efforts, despite the recognition by many managers that the changing conditions are real. In this respect, scenario planning has emerged as a useful approach for envisioning potential alternative futures under conditions of high 
Table 9 HSI Statistics for Pinfish

\begin{tabular}{|c|c|c|c|c|c|c|c|c|c|c|c|c|}
\hline \multirow[t]{4}{*}{ Basin } & Statistic & N po & SLO & $\mathrm{SL}+$ & SL+ & $\mathrm{SL}+$ & $\mathrm{SL}+$ & SLO & SL+ & SL+ & $\mathrm{SL}+$ & SL+ \\
\hline & & & EVPO & EVPO & EVP+ & EVP+ & EVP+ & EVPO & EVPO & EVP+ & EVP+ & EVP+ \\
\hline & & & RFO & RFO & RFO & $\mathrm{RF}+$ & $\mathrm{RF}-$ & RFO & RFO & RFO & $\mathrm{RF}+$ & $\mathrm{RF}-$ \\
\hline & & & TO & TO & TO & T0 & TO & $\mathrm{T}+$ & $\mathrm{T}+$ & $\mathrm{T}+$ & $\mathrm{T}+$ & $\mathrm{T}+$ \\
\hline \multirow{3}{*}{$\begin{array}{l}\text { Florida } \\
\text { Bay }\end{array}$} & Mean & & 0.488 & 0.485 & 0.498 & 0.480 & 0.516 & 0.440 & 0.431 & 0.444 & 0.427 & 0.462 \\
\hline & Median & & 0.484 & 0.467 & 0.490 & 0.460 & 0.524 & 0.416 & 0.382 & 0.404 & 0.374 & 0.432 \\
\hline & & & 0.303 & 0.312 & 0.312 & 0.313 & 0.310 & 0.302 & 0.308 & 0.310 & 0.309 & 0.310 \\
\hline \multirow{3}{*}{$\begin{array}{l}\text { Sampling } \\
\text { region }\end{array}$} & Mean & & 0.548 & 0.527 & 0.535 & 0.525 & 0.546 & 0.498 & 0.470 & 0.478 & 0.469 & 0.489 \\
\hline & Medi & & 0.578 & 0.541 & 0.556 & 0.539 & 0.576 & 0.496 & 0.437 & 0.451 & 0.436 & 0.470 \\
\hline & Std. Dev. & & 0.335 & 0.334 & 0.333 & 0.335 & 0.330 & 0.337 & 0.331 & 0.331 & 0.333 & 0.330 \\
\hline \multirow[t]{3}{*}{ West } & Mean & & 0.557 & 0.541 & 0.550 & 0.538 & 0.564 & 0.499 & 0.479 & 0.489 & 0.477 & 0.501 \\
\hline & Median & & 0.587 & 0.550 & 0.568 & 0.543 & 0.591 & 0.490 & 0.446 & 0.464 & 0.441 & 0.487 \\
\hline & Std. Dev. & & 0.314 & 0.316 & 0.315 & 0.318 & 0.311 & 0.316 & 0.316 & 0.316 & 0.317 & 0.313 \\
\hline \multirow{3}{*}{$\begin{array}{l}\text { East in- } \\
\text { shore }\end{array}$} & Mean & & 0.194 & 0.264 & 0.283 & 0.258 & 0.311 & 0.179 & 0.241 & 0.260 & 0.235 & 0.287 \\
\hline & Med & & 0.001 & 0.030 & 0.047 & 0.024 & 0.080 & 0.001 & 0.020 & 0.032 & 0.016 & 0.061 \\
\hline & Std. & & 0.319 & 0.348 & 0.356 & 0.347 & 0.363 & 0.306 & 0.331 & 0.340 & 0.331 & 0.348 \\
\hline \multirow{3}{*}{$\begin{array}{l}\text { West in- } \\
\text { shore }\end{array}$} & Mean & & 0.500 & 0.480 & 0.497 & 0.475 & 0.521 & 0.473 & 0.437 & 0.454 & 0.434 & 0.477 \\
\hline & Med & & 0.455 & 0.440 & 0.485 & 0.430 & 0.538 & 0.375 & 0.343 & 0.382 & 0.331 & 0.433 \\
\hline & Std. Dev. & & 0.419 & 0.385 & 0.385 & 0.389 & 0.380 & 0.418 & 0.380 & 0.381 & 0.383 & 0.378 \\
\hline \multirow[t]{3}{*}{ East } & Mean & & 0.305 & 0.334 & 0.359 & 0.327 & 0.395 & 0.279 & 0.300 & 0.325 & 0.294 & 0.359 \\
\hline & Media & & 0.127 & 0.193 & 0.241 & 0.170 & 0.322 & 0.094 & 0.141 & 0.186 & 0.124 & 0.261 \\
\hline & Std. Dev. & & 0.354 & 0.346 & 0.350 & 0.348 & 0.348 & 0.341 & 0.331 & 0.336 & 0.332 & 0.337 \\
\hline
\end{tabular}

All statistics are calculated across time. For regions, values were first spatially averaged, weighting each contributing basin value by the area of the respective basin. Sparkline mini-plots show the relative trend across values in each row, normalized to the range of that row

uncertainty and high impacts (Schoemaker 1995). Under this approach, managers can visualize a suite of potential future outcomes and develop adaptation strategies to deal with them.

The scenarios we examined bracket the expected future conditions, and thus provide a framework for managers to examine responses of species under different conditions. When a species is projected to respond similarly under varying scenarios, strategies are simpler to envision and craft. Alternatively, when a species response is different under different projected outcomes, the adaptation strategies may become divergent.

Climate change will not be detrimental to all species, and there are likely to be winner and losers, as well as some species and some areas that show minimal impact (Somero 2010; Loya et al. 2001; Fabricius et al. 2011; Fulton 2011). In this study, goldspotted killifish and pinfish appear to be the only clear losers in all scenarios, with both species showing a greater than $15 \%$ decrease in optimal habitat under all scenarios (Table 11). Rainwater killifish also lose optimal habitat under all scenarios, though their combined good plus optimal habitat is relatively unchanged under all potential changes. Habitat for juvenile lobsters increased under all of the climate change scenarios except the temperature increase-only scenario, whereas habitat suitability for the remaining species varied between improved or degraded conditions in the different scenarios.

Temperature increases alone negatively affected the availability of optimal habitat for all species, except that of juvenile spotted seatrout. This is likely because many of the species are already living near their thermal optimum. The impact of sea level rise and the other variables that affected salinity was less clear. Both mojarra and lobster benefited from the expansion of their optimal habitat and a decrease of their poor habitat areas. The middle quartiles of habitat suitability expanded for all of the other species, whereas their areas of both optimal and poor habitat declined to varying degrees (Fig. 6).

Scenarios with both salinity and temperature changes resulted in varying responses among the species. Salinity had little effect on the habitat suitability distributions of spotted seatrout and remained very similar to those where 
Table 10 HSI statistics for juvenile lobster

\begin{tabular}{|c|c|c|c|c|c|c|c|c|c|c|c|c|}
\hline \multirow[t]{4}{*}{ Basin } & Statistic & Sparkline & SLO & SL+ & SL+ & $\mathrm{SL}+$ & SL+ & SLO & $\mathrm{SL}^{+}$ & $\mathrm{SL}^{+}$ & SL+ & $\mathrm{SL}^{+}$ \\
\hline & & & EVPO & EVPO & EVP+ & EVP+ & EVP+ & EVPO & EVPO & EVP+ & EVP+ & EVP+ \\
\hline & & & RFO & RFO & RFO & $\mathrm{RF}+$ & $\mathrm{RF}-$ & RFO & RFO & RFO & $\mathrm{RF}+$ & $\mathrm{RF}-$ \\
\hline & & & TO & TO & TO & TO & T0 & $\mathrm{T}+$ & $\mathrm{T}+$ & $\mathrm{T}+$ & $\mathrm{T}+$ & $\mathrm{T}+$ \\
\hline \multirow{3}{*}{$\begin{array}{l}\text { Florida } \\
\text { Bay }\end{array}$} & Mean & & 0.601 & 0.655 & 0.655 & 0.652 & 0.657 & 0.547 & 0.594 & 0.594 & 0.591 & 0.596 \\
\hline & dian & & 0.717 & 0.797 & 0.797 & 0.792 & 0.805 & 0.655 & 0.729 & 0.729 & 0.729 & 0.743 \\
\hline & ev. & & 0.325 & 0.347 & 0.348 & 0.346 & 0.349 & 0.371 & 0.397 & 0.398 & 0.396 & 0.399 \\
\hline \multirow{3}{*}{$\begin{array}{l}\text { Sampling } \\
\text { region }\end{array}$} & Mean & & 0.637 & 0.683 & 0.682 & 0.682 & 0.682 & 0.579 & 0.617 & 0.616 & 0.616 & 0.616 \\
\hline & . & & 0.767 & 0.850 & 0.849 & 0.850 & 0.850 & 0.721 & 0.787 & 0.787 & .786 & 0.787 \\
\hline & & & 0.341 & 0.358 & 0.358 & 0.358 & 0.358 & 0.388 & 0.407 & 0.407 & 0.407 & 0.407 \\
\hline \multirow[t]{3}{*}{ West } & Mean & & 0.677 & 0.696 & 0.695 & 0.695 & 0.694 & 0.615 & 0.631 & 0.631 & 0.630 & 0.630 \\
\hline & $\mathrm{N}$ & & 0.843 & 0.894 & 0.889 & 0.894 & 0.887 & 0.814 & 0.839 & 0.844 & 0.834 & 0.851 \\
\hline & Std. Dev. & & 0.351 & 0.357 & 0.357 & 0.357 & 0.358 & 0.402 & 0.409 & 0.409 & 0.409 & 0.410 \\
\hline \multirow{3}{*}{$\begin{array}{l}\text { East in- } \\
\text { shore }\end{array}$} & Mean & & 0.289 & 0.441 & 0.442 & 0.431 & 0.453 & 0.271 & 0.410 & 0.411 & 0.401 & 0.419 \\
\hline & $\mathrm{N}$ & & 0.114 & 0.280 & 0.289 & 0.268 & 0.326 & 0.070 & 0.205 & 0.229 & 0.191 & 0.256 \\
\hline & & & 0.330 & 0.394 & 0.389 & 0.394 & 0.382 & 0.333 & 0.410 & 0.406 & 0.409 & 0.402 \\
\hline \multirow{3}{*}{$\begin{array}{l}\text { West in- } \\
\text { shore }\end{array}$} & Mean & & 0.452 & 0.616 & 0.614 & 0.612 & 0.616 & 0.411 & 0.547 & 0.545 & 0.544 & 0.546 \\
\hline & Med & & 0.372 & 0.871 & 0.863 & 0.859 & 0.858 & 0.218 & 0.560 & 0.561 & 0.557 & 0.564 \\
\hline & Std. Dev. & & 0.377 & 0.403 & 0.402 & 0.403 & 0.402 & 0.397 & 0.432 & 0.432 & 0.432 & 0.431 \\
\hline \multirow[t]{3}{*}{ East } & Mean & & 0.441 & 0.571 & 0.574 & 0.560 & 0.584 & 0.403 & 0.518 & 0.520 & 0.509 & 0.529 \\
\hline & & & 0.304 & 0.637 & 0.629 & 0.607 & 0.658 & 0.254 & 0.463 & 0.491 & 0.451 & 0.545 \\
\hline & Std. Dev. & & 0.359 & 0.365 & 0.364 & 0.367 & 0.361 & 0.380 & 0.403 & 0.403 & 0.404 & 0.401 \\
\hline
\end{tabular}

All statistics are calculated across time. For regions, values were first spatially averaged, weighting each contributing basin value by the area of the respective basin. Sparkline mini-plots show the relative trend across values in each row, normalized to the range of that row

temperature alone increased. Salinity and temperature effects appear to cancel out one another in the response of mojarra to the scenarios incorporating both factors, with habitat suitability distributions slightly worse than the baseline scenario. Gray snapper and rainwater killifish both experienced an expansion of the middle quartiles and decrease in optimal and poor habitat quartiles for the scenarios with both salinity and temperature changes compared to the baseline scenario and the scenarios that only adjusted salinity or temperature. Optimal habitat for lobsters increased in response to salinity changes, but poor habitat area increased in response to temperature. The responses with both temperature and salinity reflected this as an expansion of both poor and optimal habitat and a contraction of fair and good habitat (Fig. 6).

In some cases, the effect of climate change was most pronounced during months that are currently just outside the period when a species is most likely to be observed. For example, C. nebulosus experience expansions of habitat in both April and October in the SL+_EVP+_RF+_T+ scenario, while currently the timing of their spawning season leads to most juvenile $C$. nebulosus being observed from May through October. This may indicate that some scenarios will expand the recruitment season for juvenile spotted seatrout or other species. This expansion of recruitment is likely for November, because juvenile $C$. nebulosus are currently observed at high frequencies in November in some areas of Florida Bay, if conditions are near optimal (Kelble et al. 2013a). However, the temporal distribution may be limited by the timing of spawning that may or may not undergo a phenological shift as a result of changes in physical habitat.

Areas of Florida Bay that are forecast to change habitat quality in response to climate change may be inaccessible to the juveniles for the species of interest (Fig. 4). However, sea level rise may provide the additional benefit of making more areas of Florida Bay accessible to these juveniles. Lobsters, in particular, are likely to benefit due to sea level increase because habitats that are currently inaccessible due to physical barriers associated with the banks within Florida Bay (Field and Butler 1994) may overwash with increasing frequency. This may facilitate 

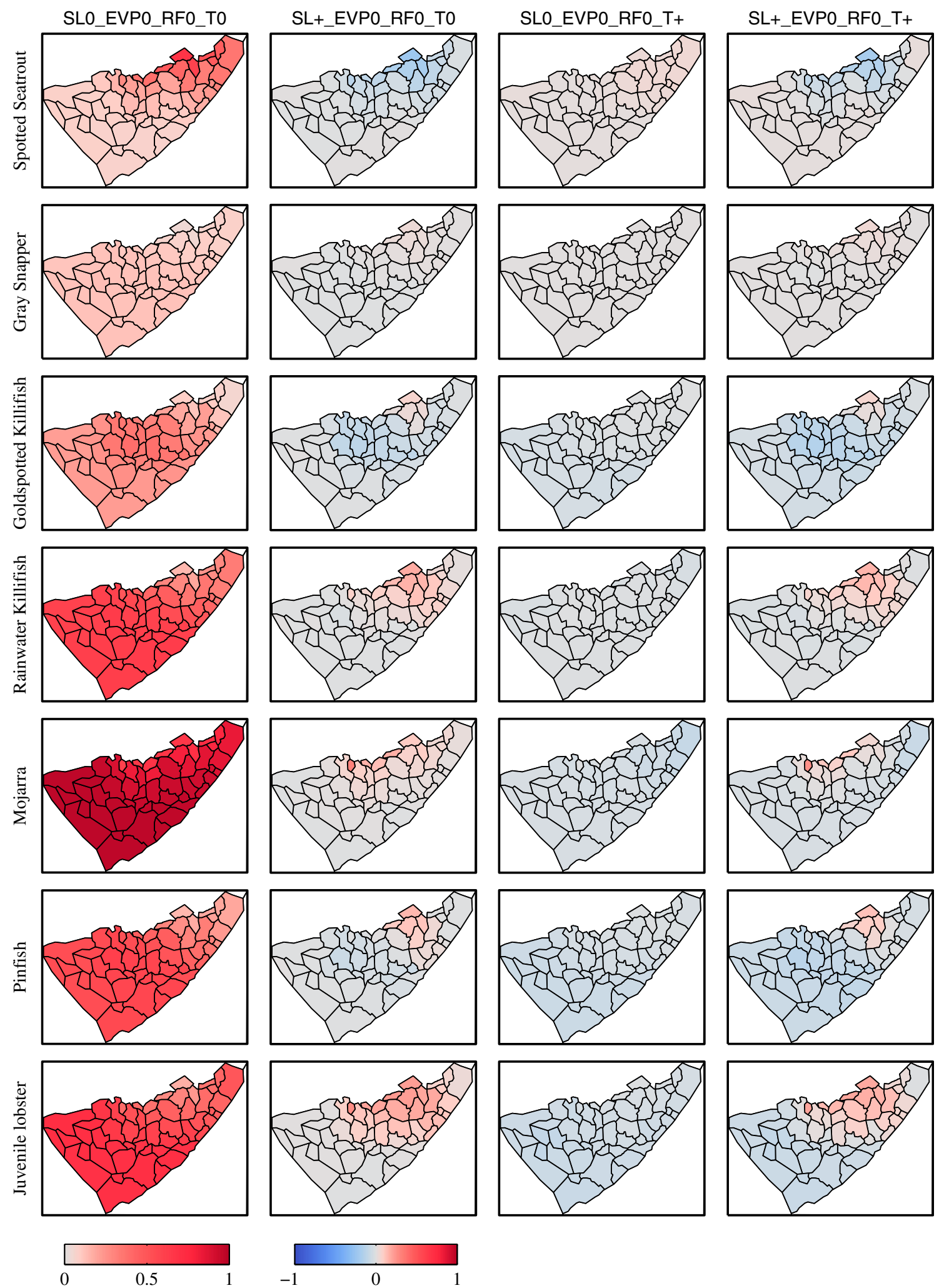

Fig. 4 Change in spatial distribution of mean HSI values. The first column of plots shows the mean HSI values in each basin under the baseline conditions. The remaining three columns show the change

between that scenario and the increased sea level only, increased temperature only, and increased sea level and temperature scenarios 

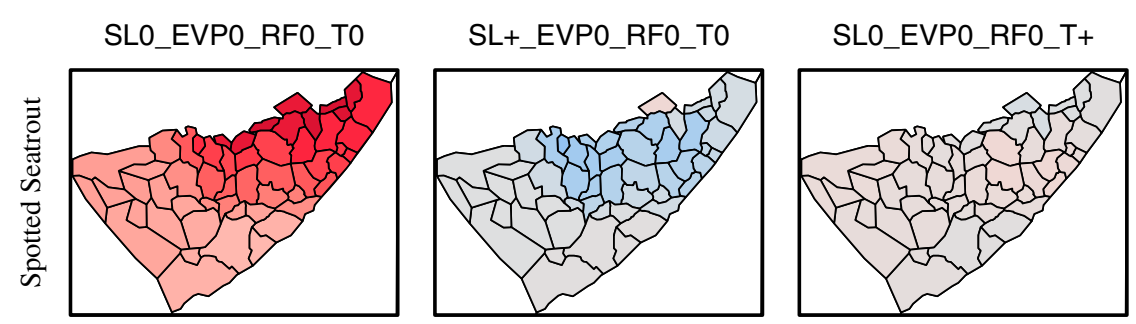

SL+_EVPO_RFO_T+
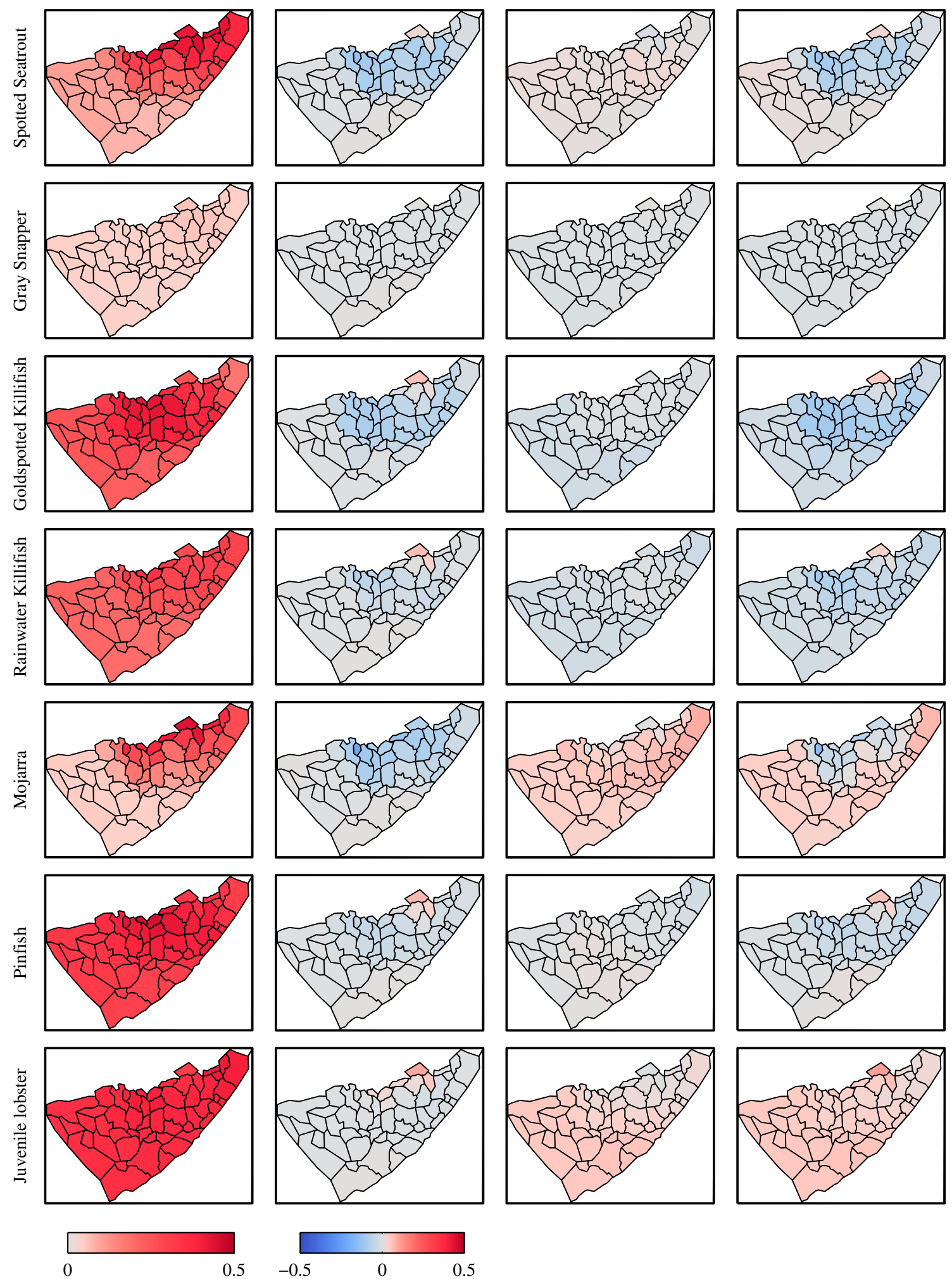

Fig. 5 Change in spatial distribution of SD of HSI values, arranged as in previous figure 
Fig. 6 Change in mean yearly distribution of sampling region area (totaling $535.86 \mathrm{~km}^{2}$ ) between the four quartiles, with dark orange, light orange, light purple, and dark purple

representing poor, fair, good, and optimal habitat, respectively. The dotted gray line indicates the $50 \%$ mark, for reference

\section{Spotted Seatrout}

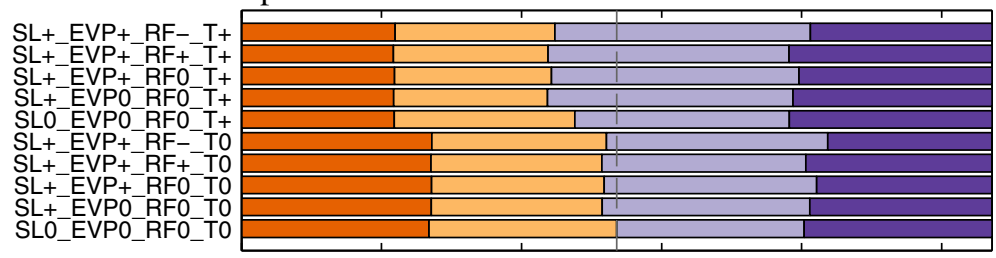

Gray Snapper

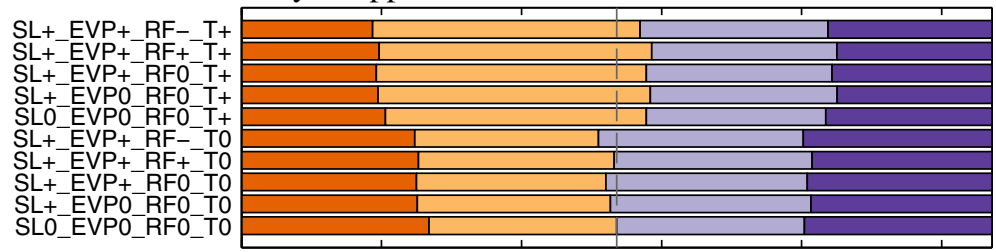

Goldspotted Killifish

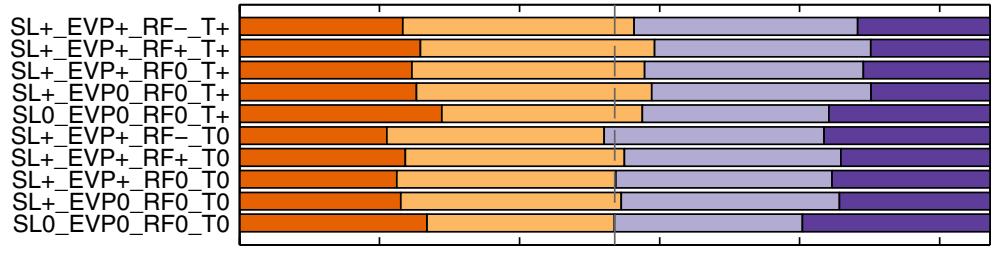

Rainwater Killifish

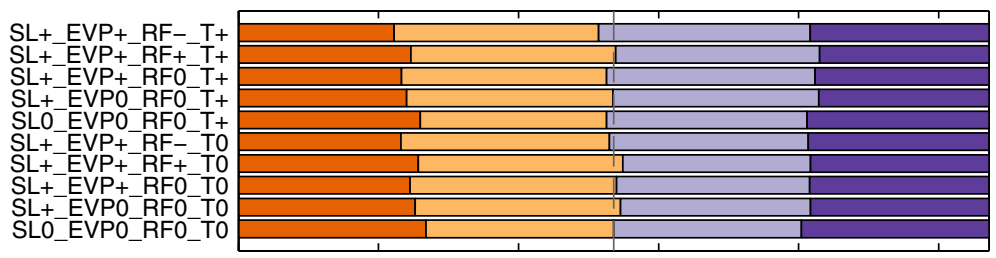

Mojarra

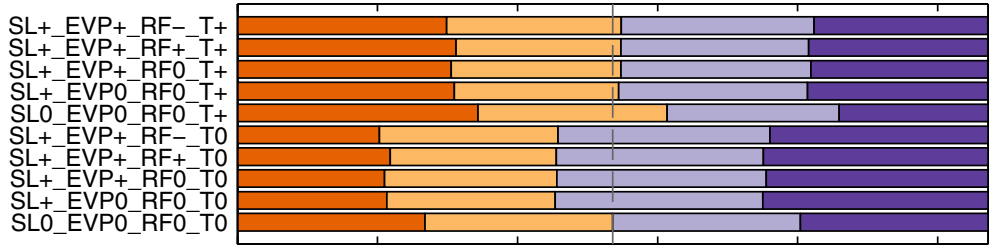

Pinfish

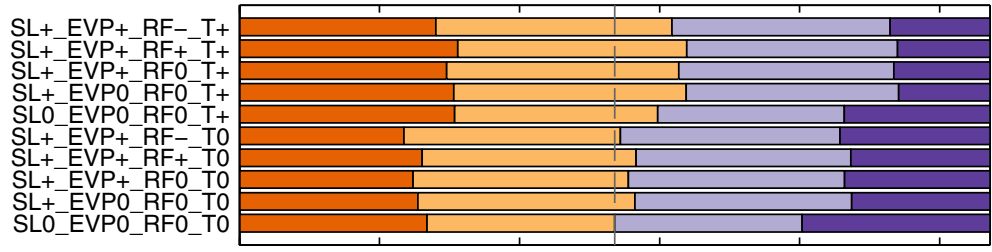

Juvenile lobster

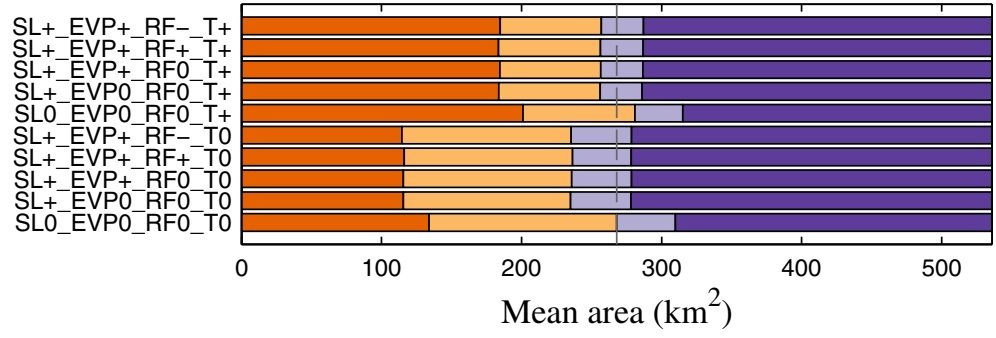


Table 11 Change in optimal habitat area, in $\mathrm{km}^{2}$

\begin{tabular}{lcclcccc}
\hline & $\begin{array}{l}\text { Spotted } \\
\text { Seatrout } \\
(134.17)\end{array}$ & $\begin{array}{l}\text { Gray Snapper } \\
(133.98)\end{array}$ & $\begin{array}{l}\text { Goldspotted } \\
\text { Killifish (133.98) }\end{array}$ & $\begin{array}{l}\text { Rainwater } \\
\text { Killifish (133.98) }\end{array}$ & $\begin{array}{l}\text { Mojarra } \\
(133.97)\end{array}$ & $\begin{array}{l}\text { Pinfish } \\
(134.17)\end{array}$ & $\begin{array}{l}\text { Juvenile } \\
\text { lobster } \\
(226.13)\end{array}$ \\
\hline SL+_EVP0_RF0_T0 & -4.21 & -4.83 & -26.58 & -6.50 & 26.82 & -35.54 & 31.59 \\
SL+_EVP+_RF0_T0 & -8.92 & -2.07 & -21.28 & -5.98 & 24.29 & -30.31 & 31.29 \\
SL+_EVP+_RF+_T0 & -1.37 & -5.60 & -27.54 & -6.67 & 26.44 & -34.91 & 31.36 \\
SL+_EVP+_RF-_T0 & -16.96 & 0.71 & -15.48 & -5.02 & 21.78 & -27.01 & 31.16 \\
SL0_EVP0_RF0_T+ & 10.58 & -15.40 & -19.03 & -4.13 & -27.70 & -30.14 & -5.38 \\
SL+_EVP0_RF0_T+ & 7.82 & -23.36 & -49.13 & -12.49 & -5.04 & -69.05 & 23.79 \\
SL+_EVP+_RF0_T+ & 3.68 & -19.85 & -43.55 & -9.85 & -7.54 & -65.60 & 23.06 \\
SL+_EVP+_RF+_T+ & 10.80 & -23.18 & -48.95 & -13.03 & -5.91 & -68.09 & 22.96 \\
SL+_EVP+_RF-_T+ & -4.58 & -16.98 & -39.50 & -6.38 & -9.86 & -62.87 & 22.60 \\
\hline
\end{tabular}

The number following each species name indicates the yearly-averaged optimal habitat under baseline conditions (SL0_EVP0_RF0_T0), and each table entry indicates the change relative to that value

larval exchange into locations that are currently inaccessible.

The HSI models presented in this paper look at impacts of physical drivers on a single species, and as such do not account for species interactions. For example, fishery species are highly dependent on other organisms, such as seagrass and macroalgae, for habitat, and thus will be affected significantly by how climate change alters those species. Scenarios that alter the density and composition of seagrass beds will likely alter most finfish distributions; likewise, juvenile lobster depend on macroalgae and sponges for habitat (Butler et al. 1997; Butler and Herrnkind 1997). Our HSI models also fail to take into consideration predator/prey interactions, either in the initial presence/absence patterns (opposite trends in the predator and prey species with respect to temperature and salinity may arise due to competitive and predatory influences on populations rather than due to the physical environment) or in the predicted change in habitat quality. For example, conditions improve for spotted seatrout under all scenarios that include temperature increase, except one; however, their prey species all show significant decreases under these scenarios. Thus, even as habitat suitability conditions may improve for spotted seatrout in these scenarios, their populations may become limited by prey availability.

The climate change scenarios representing alternative potential futures for Florida Bay resulted in a variety of changes in habitat suitability for the species covered in this study; however, few of these responses were large. In fact, only pinfish showed a greater than $50 \%$ change in optimal habitat under any of the scenarios. This suggests that the effects of climate change on Florida Bay's estuarine fauna may not be as great as what might be experienced by other components of the ecosystem, particularly the stenohaline and stenothermic taxa that inhabit the freshwater and marine ecotones along the northern and southern boundaries of Florida Bay, respectively. However, this analysis should be a considered a first-order approximation of potential speciesspecific responses to climate change as it is based on a simple correlative model rather than specific mechanisms, and these correlations may well change as species potentially adjust and adapt to previously unseen climate conditions. In addition, this model does not incorporate species interactions and other ecosystem-related factors that will likely influence the response of specific species to climate change.

This exercise is a step toward evaluating potential relative changes in system carrying capacity as mediated by climate-driven changes in habitat quality. As noted above, there are numerous interactions among biotic and abiotic system components that have not been captured here, but that clearly deserve consideration and integration as more data become available and as complementary models (e.g., hydrodynamic, trophic, demographic, human behavioral) become more comprehensive and spatiotemporally resolved. Realistic predictions of how the gamut of climate-related changes in and around Florida Bay will ultimately affect regional patterns of human distribution, freshwater consumption/diversion, watershed development, coastal pollution, and fishing pressure will depend on close collaboration and coordination among a diversity of technical experts. 
Base
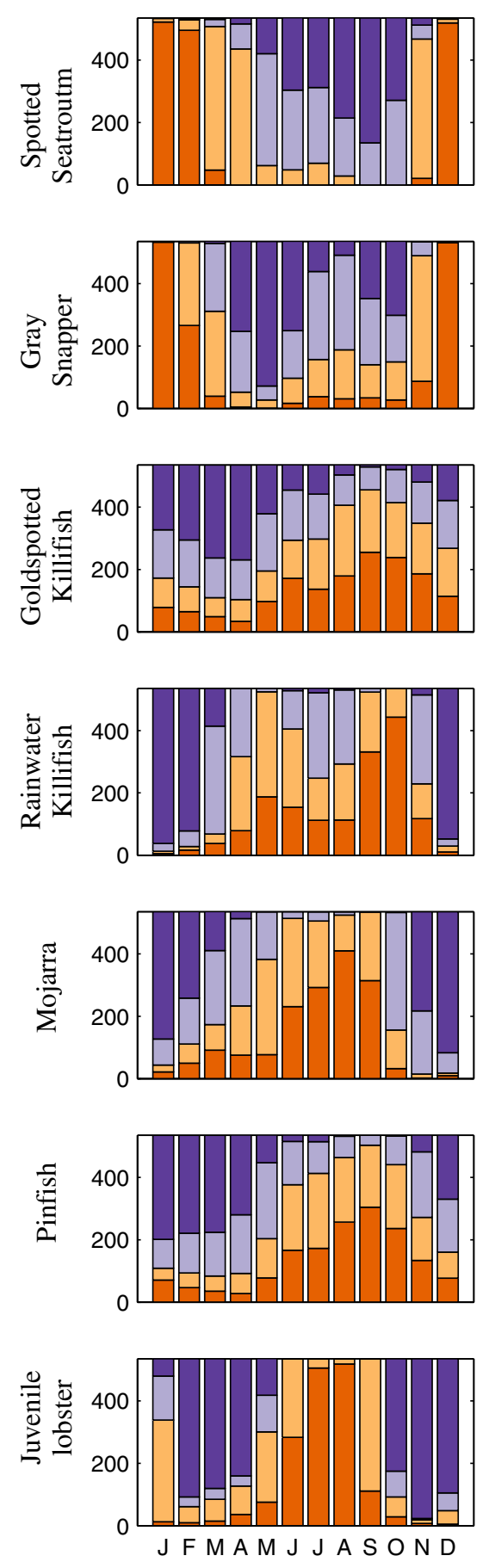

Worst

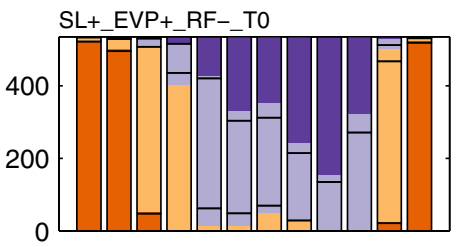

SL+ EVPO RFO T+

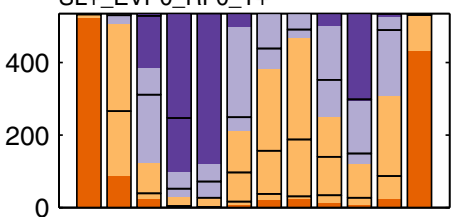

SL+_EVPO_RFO_T+
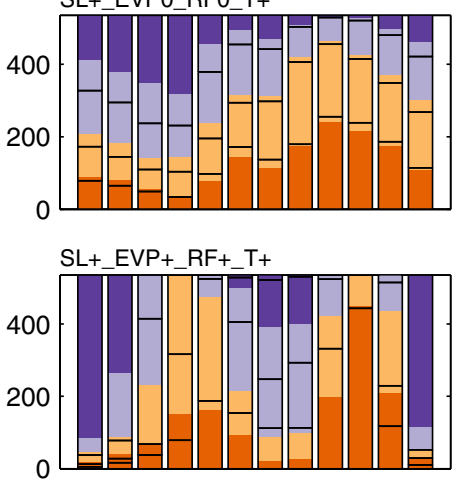

SLO_EVPO_RFO_T+
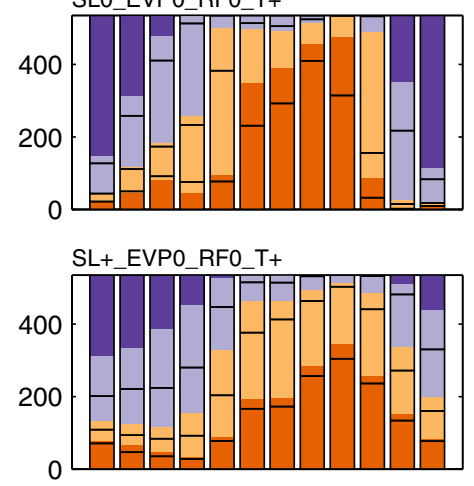

SLO_EVPO_RFO_T+

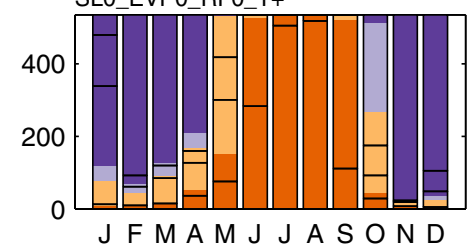

Best

$\mathrm{SL}+\mathrm{EVP}+$ +RF+_T+

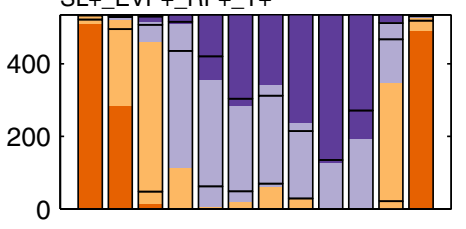

$\mathrm{SL}+\mathrm{EVP}+\mathrm{RF}-\mathrm{TO}$
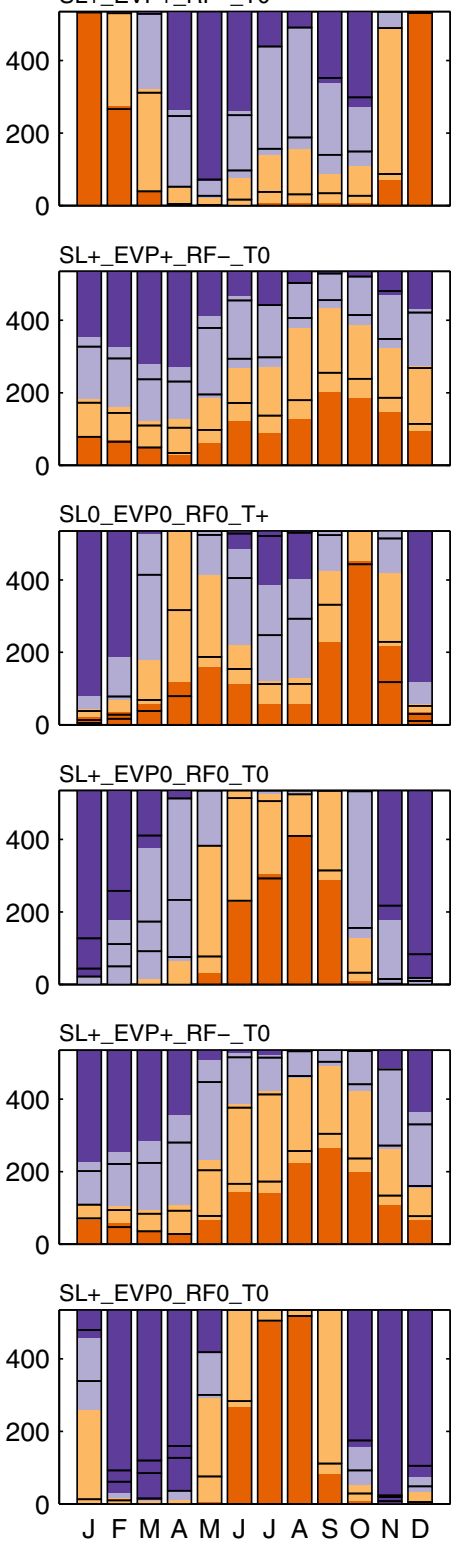

Fig. 7 Seasonal pattern in sampling region area distribution among quartiles under the baseline scenario, the scenario that results in the most habitat lost (or least gained) for each species, and the scenario that results in the most habitat gained for each species. Colors are the

Acknowledgments This research was supported by award NA12OAR4310105 by the National Oceanic and Atmospheric Administration Climate Program Office's Coastal and Ocean Climate Applications Program to the University of Miami. Funding for this project is provided by the U.S. Army Corps of Engineers as part of the same as Fig. 6, with dark orange, light orange, light purple, and dark purple representing poor, fair, good, and optimal habitat, respectively. The vertical axis represents sampling region area in $\mathrm{km}^{2}$

Comprehensive Everglades Restoration Plan (CERP), Restoration Coordination \& Verification (RECOVER), Monitoring and Assessment Plan (MAP) (http://www.evergladesplan.org/pm/recover.aspx). RECOVER is an interagency collaboration between federal agencies, Florida state agencies, and Native American Tribes supporting the 
integration of scientific principals and information into the CERP. Additional funding support is provided by NOAA. Thank you to Frank Marshall of the Cetacean Logic Foundation for assistance with the FATHOM model. Work was supported in part by the National Marine Fisheries Service.

\section{References}

Barbier EB, Hacker SD, Kennedy C, Koch EW, Silliman BR (2011) The value of estuarine and coastal ecosystem services. Ecol Monogr 81(2):169-193. doi:10.1890/10-1510.1

Boyer JN, Kelble CR, Ortner PB, Rudnick DT (2009) Phytoplankton bloom status: chlorophyll a biomass as an indicator of water quality condition in the southern estuaries of Florida, USA. Ecol Indicators 9(6, Supplement):S56-S67. doi:10.1016/j.ecolind. 2008.11.013

Butler MJ, Herrnkind WF (1997) A test of recruitment limitation and the potential for artificial enhancement of spiny lobster (Раnиlirus argus) populations in Florida. Can J Fish Aquat Sci 52(2):452-463

Butler MJ, Hunt JH, Herrnkind WF, Childress MJ, Bertelsen R, Sharp W, Matthews T, Field JM, Marshall HG (1995) Cascading disturbances in Florida Bay, USA: cyanobacteria blooms, sponge mortality, and implications for juvenile spiny lobsters Panulirus argus. Mar Ecol Progr Ser 129:119-125

Butler M (2009) Effects of Florida Bay and Florida keys feasibility study alternatives on Spiny lobster populations and Spongeoctocoral communities in the Florida Bay and Florida keys regions. Final Report to South Florida Water Management District, West Palm Beach, FL, p 23

Butler M, Herrnkind W, Hunt J (1997) Factors affecting the recruitment of juvenile Caribbean spiny lobsters dwelling in macroalgae. Bull Mar Sci 61(1):3-19. http://www.ingentacon nect.com/content/umrsmas/bullmar/1997/00000061/00000001/ $\operatorname{art} 00002$

Chang YJ, Sun CL, Chen Y, Yeh SZ, DiNardo G, Su NJ (2013) Modelling the impacts of environmental variation on the habitat suitability of swordfish, Xiphias gladius, in the equatorial Atlantic Ocean. ICES J Mar Sci 70(5):1000-1012. doi:10. 1093/icesjms/fss190

Cline TJ, Bennington V, Kitchell JF (2013) Climate change expands the spatial extent and duration of preferred thermal habitat for Lake Superior fishes. PLoS ONE 8(4):1-8. doi:10.1371/journal. pone.0062279

Cook G, Fletcher P, Kelble C (2014) Towards marine ecosystem based management in South Florida: investigating the connections among ecosystem pressures, states, and services in a complex coastal system. Ecol Indicators. doi:10.1016/j.ecolind. 2013.10.026

Cosby B, Nuttle W, Fourqurean J (2004) FATHOM-Flux Accounting and Tidal Hydrology at the Ocean Margin: Florida Bay Simulation 1991-2002, Updated Model and Preliminary Results. Report for the Everglades National park (ENP), National Park Service Deptof Environmental Sciences, University of Virginia, Charlottesville, VA

Ehrhardt N, Puga R, Butler M (2010) Large ecosystem dynamics and fishery management concepts: The Caribbean spiny lobster, Panulirus argus, fisheries. In: Fanning L, Mahon R, McConney $\mathrm{P}$ (eds) Towards Marine Ecosystem-Based Management in the Wider Caribbean. Amsterdam University Press, Amsterdam

Estuar Coast Shelf S Special Section (2012) LOICZ-IHDP special section. Estuarine Coastal Shelf Sci 96:1-59
Fabricius KE, Langdon C, Uthicke S, Humphrey C, Noonan S, De'ath G, Okazaki R, Muehllehner N, Glas MS, Lough JM (2011) Losers and winners in coral reefs acclimatized to elevated carbon dioxide concentrations. Nat Clim Change 1(6):165-169. doi:10. 1038/nclimate 1122

Field J, Butler M (1994) The influence of temperature, salinity, and postlarval transport on the distribution of juvenile spiny lobsters, Panulirus argus (Latreille, 1804), in Florida Bay. Crustaceana 67(1):26-45. doi:10.2307/20104964

Fourqurean J, Robblee M (1999) Florida Bay: a history of recent ecological changes. Estuaries 22(2B):345-357. http://www. springerlink.com/index/vh24236250573557.pdf

Fulton EA (2011) Interesting times: winners, losers, and system shifts under climate change around Australia. ICES J Mar Sci 68(6):1329-1342

Goldstein JS, Butler MJI (2009) Behavioral enhancement of onshore transport by postlarval Caribbean spiny lobster (Panulirus argus). Limnol Oceanogr 54(5):1669-1678. doi:10.4319/lo. 2009.54.5.1669

Halpern BS, Walbridge S, Selkoe K, Kappel CV, Micheli F, D'Agrosa C, Bruno JF, Casey KS, Ebert C, Fox HE, Fujita R, Heinemann D, Lenihan HS, Madin EMP, Perry MT, Selig ER, Spalding M, Steneck R, Watson R (2008) A global map of human impact on marine ecosystems. Science (New York, NY) 319(5865):948-52. doi:10.1126/science.1149345

Havens KE, Steinman AD (2013) Ecological responses of a large shallow lake (Okeechobee,Florida) to climate change and potential future hydrologicregimes. Environ Manage. doi:10. 1007/s00267-013-0189-3

Herrnkind W, Butler M IV, Hunt J, Childress M (1997) The role of physical refugia: implications from a mass sponge die-off in a lobster nursery. Mar Freshw Res 48:759-770

Jones MC, Dye SR, Fernandes JA, Frolicher TL, Pinnegar JK, Warren R, Cheung WWL (2013) Predicting the impact of climate change on threatened species in UK waters. PLoS ONE 8(1):1-13. doi:10.1371/journal.pone.0054216

Kelble CR, Johns EM, Nuttle WK, Lee TN, Smith RH, Ortner PB (2007) Salinity patterns of Florida Bay. Estuarine, Coastal Shelf Sci 71(1-2):318-334. doi:10.1016/j.ecss.2006.08.006

Kelble C, Browder J, Visser L, Contillo J (2013a) 2013 Annual Report: Juvenile Sportfish Monitoring in Florida Bay. Everglades National Park, United States Army Corps of Engineers

Kelble C, Loomis D, Lovelace S, Ortner P, Fletcher P, Cook G, Lorenz J, Boyer J (2013b) The EBM-DPSER conceptual model: Integrating ecosystem services into the DPSIR framework. PLoS ONE 8(8):70-766. doi:10.1371/journal.pone.0070766

Lee TN, Johns E, Melo N, Smith RH, Ortner P, Smith D (2006) On Florida Bay hypersalinity and water exchange. Bull Mar Sci 79(2):301-327

Light SS, Dineen JW (1994) Water control in the Everglades: a historical perpective. In: Davis SM, Ogden JC (eds) Everglades: the ecosystem and its restoration, chap 1. St. Lucie Press, Delray Beach, pp 47-84

Lotze HK, Lenihan HS, Bourque BJ, Bradbury RH, Cooke RG, Kay MC, Kidwell SM, Kirby MX, Peterson CH, Jackson JBC (2006) Depletion, degradation, and recovery potential of estuaries and coastal seas. Science (New York, NY) 312(5781):1806-1809. doi:10.1126/science.1128035

Loya Y, Sakai K, Yamazoto K, Nakano Y, Sambali H, van Woesik R (2001) Coral bleaching: the winners and the losers. Ecol Lett 4:122-131

Madden CJ, Rudnick DT, McDonald AA, Cunniff KM, Fourqurean JW (2009) Ecological indicators for assessing and communicating seagrass status and trends in Florida Bay. Ecol Indicators 9(6, Supplement):S68-S82. doi:10.1016/j.ecolind.2009.02.004 
Marshall FE, Wingard GL (2012) Florida Bay Salinity and Everglades Wetlands Hydrology circa 1900 CE: A Compilation of Paleoecology-Based Statistical Modeling Analyses Florida Bay Salinity and Everglades Wetlands Hydrology circa 1900 CE : A Compilation of Paleoecology-Based Statistical. USGS Open-File Report 20121054

Marshall FE, Wingard GL, Pitts P (2008) A simulation of historic hydrology and salinity in Everglades National Park: Coupling Paleoecologic Assemblage Data with Regression Models. Estuaries Coasts 32(1):37-53. doi:10.1007/s12237-008-9120-1

McIvor CC, Ley JA, Bjork RD (1994) Changes in freshwater inflow from the Everglades to Florida Bay including effects on biota and biotic processes: a review. In: Davis SM, Ogden JC (eds) Everglades: the ecosystem and its restoration. St. Lucie Press, Delray Beach, pp 117-148

Misra V, Moeller L, Stefanova L, Chan S, O’Brien JJ, Smith TJ, Plant N (2011) The influence of the Atlantic Warm Pool on the Florida panhandle sea breeze. J Geophys Res 116:D00Q06. doi:10.1029/ 2010JD015367

Obeysekera J (2013) Validating climate models for computing evapotranspiration in hydrologic studies: how relevant are climate model simulations over Florida? Reg Environ Change 13(S1):81-90. doi:10.1007/s10113-013-0411-0

Obeysekera J, Barnes J, Nungesser M (2014) Climate sensitivity runs and regional hydrologic modeling for predicting the response of the greater florida everglades ecosystem to climate change. Environ Manage. doi:10.1007/s00267-014-0315-x

Osborne J, Schmidt TW, Kalafarski J (2006) Year 2005 Annual Marine Fisheries Report. Tech. rep, Everglades National Park, Homestead, FL

Pendleton L (2010) The economic and market value of coasts and estuaries: What's at stake? Restore America's Estuaries

Pond S, Fissel DB, Paulson CA (1974) A note on bulk aerodynamic coefficients for sensible heat and moisture fluxes. BoundaryLayer Meteorol 6(1-2):333-339. doi:10.1007/BF00232493
Powell AB (2003) Larval abundance, distribution, and spawning habits of spotted seatrout (Cynoscion nebulosus) in Florida Bay, Everglades National Park, Florida. Fish Bull 101:704-711

Powell AB, Thayer G, Lacroix M, Cheshire R (2007) Juvenile and small resident fishes of Florida Bay, a critical habitat in the Everglades National Park. Florida. NOAA Professional Paper NMFS 6:220

Schoemaker PJ (1995) Scenario planning: a tool for strategic thinking. Sloan Manag Rev 36:25-40. http://www.intertech.ps/ idmc/userfiles/file/stadies/ScenarioPlanning.pdf

Smith NP (2000) Evaporation and the precipitation-evaporation balance in Florida Bay. Florida Sci 63(2):72-83

Smith T, Hudson J, Robblee M, Powell G, Isdale P (1989) Freshwater flow from the everglades to Florida Bay-a historical reconstruction based on fluorescent banding in the coral Solenastrea-Bournoni. Bull Mar Sci 44(1):274-282

Somero GN (2010) The physiology of climate change: how potentials for acclimatization and genetic adaptation will determine 'winners' and 'losers'. J Exp Biol 213:912-920. doi:10.1242/ jeb.037473

South Florida Natural Resources Center Everglades National Park (2013) DataForEVER Dataset. Data available on request from: EVER_data_request@nps.gov

Swart PK, Healy GF, Dodge RE, Kramer P, Hudson J, Halley RB, Robblee MB (1996) The stable oxygen and carbon isotopic record from a coral growing in Florida Bay: a 160 year record of climatic and anthropogenic influence. Palaeogeogr Palaeoclimatol Palaeoecol 123(1-4):219-237

Thayer GW, Powell AB, Hoss DE (1999) Composition of larval, juvenile, and small adult fishes relative to changes in environmental conditions in Florida Bay. Estuaries 22(2):518-533

Tilmant J (1989) A history and an overview of recent trends in the fisheries of Florida Bay. Bull Mar Sci 44(1):3-33. http://www. ingentaconnect.com/content/umrsmas/bullmar/1989/00000044/ 00000001/art00002 